Westwood, A. R., C. Staicer, P. Sölymos, S. Haché, T. Fontaine, E. Bayne, and D. Mazerolle. 2019. Estimating the conservation value of protected areas in Maritime Canada for two species at risk: the Olive-sided Flycatcher (Contopus cooperi) and Canada Warbler (Cardellina canadensis). Avian Conservation and Ecology 14(1):16. https://doi.org/10.5751/ACE-01359-140116

Copyright (C 2019 by the author(s). Published here under license by the Resilience Alliance.

Research Paper, part of a Special Feature on Conservation of Boreal Birds

\title{
Estimating the conservation value of protected areas in Maritime Canada for two species at risk: the Olive-sided Flycatcher (Contopus cooperi) and Canada Warbler (Cardellina canadensis)
}

\author{
Alana R. Westwood ${ }^{1,2}$, Cindy Staicer ${ }^{3}$, Péter Sólymos ${ }^{1,4,5}$, Samuel Haché ${ }^{6}$, Trish Fontaine ${ }^{7}$, Erin M. Bayne ${ }^{8}$ and Dan Mazerolle 9 \\ ${ }^{1}$ Boreal Avian Modelling Project, Edmonton, Alberta, Canada, ${ }^{2}$ Dalhousie University, Halifax, Nova Scotia, Canada, \\ ${ }^{3}$ Department of Biology, Dalhousie University, Halifax, Nova Scotia, Canada, ${ }^{4}$ Alberta Biodiversity Monitoring Institute, \\ Edmonton, Alberta, ${ }^{5}$ Department of Biological Sciences, University of Alberta, Edmonton, Alberta, ${ }^{6}$ Canadian Wildlife Service, \\ Environment and Climate Change Canada, Yellowknife, Northwest Territories, Canada, ${ }^{7}$ Department of Renewable Resources, \\ University of Alberta, Alberta, Canada, ${ }^{8}$ Department of Biological Sciences, University of Alberta, Edmonton, Alberta, Canada, \\ ${ }^{9}$ Canadian Forest Service, Natural Resources Canada
}

\begin{abstract}
The Olive-sided Flycatcher (Contopus cooperi) and Canada Warbler (Cardellina canadensis) are threatened landbirds in Canada and parts of the U.S. Both species are subjects of recent conservation and management interest. Protected areas are a key tool for managing populations of species at risk, and Canadian national parks may serve as important refuges in an increasingly fragmented landscape. However, the potential role that Canadian national parks may play in the recovery of these species is unclear. We used the Boreal Avian Modelling Project point count database to build Poisson log-linear models using forward stepwise variable selection to predict population density and distribution of these two threatened species in four national parks in Maritime Canada. We also predicted population density in areas of equivalent size in the same ecoregions outside the parks for comparison. Because forested wetlands, a key habitat for these species in this region, are difficult to represent with available spatial data, we tested the effectiveness of different remote sensing products. We tested GIS layers based on aerial photography wetlands (WETLANDS), depth to water table (WETNESS), and WETNESS as interacted with forest cover from aerial photography (WETxFOR). The bestperforming models for the Olive-sided Flycatcher used WETxFOR, whereas WETNESS performed best for the Canada Warbler. Anthropogenic disturbance and proximity to roads had a negative effect on predicted density for both species. Protected areas showed slightly higher Olive-sided Flycatcher population densities than nearby areas, but not so for the Canada Warbler. Our results provide the first population density and population size estimates for these species in these parks, and novel information on the impacts of anthropogenic disturbance on predicted population density. These results can inform conservation and management in this region and our approach can be replicated in other regions to support ongoing recovery efforts.
\end{abstract}

\section{Évaluation de la valeur de conservation d'aires protégées dans les Maritimes, Canada, pour deux espèces en péril : le Moucherolle à côtés olive (Contopus cooperi) et la Paruline du Canada (Cardellina canadensis)}

RÉSUMÉ. Le Moucherolle à côtés olive (Contopus cooperi) et la Paruline du Canada (Cardellina canadensis) sont des oiseaux terrestres menacés au Canada et dans certaines parties des États-Unis. Ces deux espèces font depuis peu l'objet d'un intérêt de conservation et de gestion. Les aires protégées représentent des outils stratégiques pour gérer les populations d'oiseaux en péril, et les parcs nationaux canadiens serviront peut-être d'importants refuges dans la foulée de la fragmentation grandissante du paysage. Toutefois, le rôle potentiel que les parcs nationaux canadiens pourraient jouer dans le rétablissement de ces espèces est incertain. À partir des points d'écoute de la base de données du Projet de modélisation de l'avifaune boréale, nous avons conçu des modèles loglinéaires de Poisson et sélectionné les variables au moyen de régression multiple ascendante pour prédire la densité et la répartition de ces deux espèces menacées dans quatre parcs nationaux dans les Maritimes, Canada. Nous avons aussi prédit la densité dans des aires de taille équivalente dans les mêmes écorégions, mais hors des parcs, à des fins de comparaison. En raison de la difficulté à représenter les milieux humides forestiers, un habitat clé pour ces espèces dans cette région, à partir des données spatiales disponibles, nous avons testé l'efficacité de différents produits de télédétection. Nous avons testé des couches SIG fondées sur des photographies aériennes de milieux humides (WETLANDS), des chartes de profondeur d'eau (WETNESS), et l'interaction de WETNESS avec le couvert forestier déterminé à partir de photographies aériennes (WETxFOR). Les meilleurs modèles pour le Moucherolle à côtés olive ont été créés à partir de WETxFOR, tandis que WETNESS s'est avéré le meilleur pour la Paruline du Canada. Les perturbations d'origine anthropique et la proximité des routes ont eu des effets négatifs sur les densités prédites pour les deux espèces. Les aires protégées hébergeaient des densités de moucherolles sensiblement plus élevées que les aires environnantes, mais ce n'était pas le cas pour la Paruline du Canada. Nos résultats sont les premiers à chiffrer les densités et la taille des populations pour ces espèces dans 
ces parcs. Ils présentent également de l'information inédite quant aux impacts des perturbations d'origine anthropique sur les densités prédites de population. Ces résultats peuvent être utilisés pour orienter la conservation et la gestion dans cette région, et notre approche peut être reproduite dans d'autres régions pour appuyer les efforts de rétablissement en cours.

Key Words: Canada Warbler; conservation; Olive-sided Flycatcher; parks and protected areas; species at risk; species distribution models

\section{INTRODUCTION}

The Olive-sided Flycatcher (Contopus cooperi) and the Canada Warbler (Cardellina canadensis) are migratory songbirds with large breeding ranges that co-occur east of the Rocky Mountains (Reitsma et al. 2010, Altman and Sallabanks 2012). Both species are listed as nationally threatened in Canada as a result of ongoing steep population declines. Decline severity is higher in the eastern portion of the range, including the Canadian Maritime provinces of New Brunswick and Nova Scotia (GC 2002, ECCC 2017). Both have been subjects of recent conservation and management interest through groups such as the Canada Warbler International Conservation (CWICI 2016) and research efforts (e.g., de Lima Pereira 2016, Haberski et al. 2016, Hunt et al. 2017, Céspedes and Bayly 2018; A. R. Westwood, D. Lambert, L. Reitsma, and D. Stralberg, unpublished manuscript.

On the eastern portion of their range, these species occur in forested wetlands (Hallworth et al. 2008a, Becker et al. 2012, Westwood 2016). Also termed "treed swamps," forested wetlands are characterized by a treed canopy atop peatland or mineral wetland, with a water table at or near the surface (NWWG 1997). The Olive-sided Flycatcher uses edges of predominantly coniferous forests alongside wetlands and gaps created by recent burns or clearcuts (Altman and Sallabanks 2012). The Canada Warbler uses forested wetlands and wet, shrubby mixedwood forests (Reitsma et al. 2010). A field study in southwestern Nova Scotia found both species mainly on forested wetland sites on organic soils (Westwood 2016).

Throughout their breeding ranges, the Canada Warbler and Olive-sided Flycatcher have experienced historical and ongoing pressures from the forestry sector (CCFM 2019). These activities tend to decrease the availability of forested wetlands and mixedwood forests (Mosseler et al. 2003, Amos-Binks et al. 2010, Berry et al. 2018) and increase landscape fragmentation (Betts et al. 2003). The impacts of anthropogenic disturbance on populations of these species is not fully known (EC 2015, 2016). Although both species will breed in postharvest areas, their population density seems to be related to the type of forest management applied, with higher density and productivity in partial and patch cuts than in clearcuts (Preston and Harestad 2007, Robertson and Hutto 2007, Spies et al. 2007, Hallworth et al. 2008a, Ball et al. 2016, Hunt et al. 2017). There is also some evidence of detrimental effects of road networks on density of these species (Miller 1999, Matsuoka et al. 2011, Haché et al. 2014).

Protected areas, regularly identified as key tools for managing species at risk (Guisan et al. 2013), can serve as important refuges for biodiversity (Deguise and Kerr 2006). In Canada, national parks are administered by Parks Canada, whose mandate also includes ensuring the ecological integrity of its lands and the protection and management of species at risk (Parks Canada 2011). Species within national parks experience disturbance from road expansion, recreation, and other managed uses, but are largely unimpacted by timber harvest and resource extraction, or they are managed at levels considerably lower than in nonprotected landscapes (GC 2017). However, the efficacy of parks and other protected areas (e.g., privately protected areas, wildlife management areas) to meet their conservation and management-related objectives remains largely unknown (Leverington et al. 2010). Two key factors limit our ability to evaluate how effectively parks protect species at risk: (1) a lack of information on species population density and distribution; and (2) limited high-resolution information on the impacts of anthropogenic disturbance.

\section{Modeling species associated with wet forest habitats}

Species distribution models (SDMs) encompass a suite of tools used to predict the distribution of a species based on specieshabitat relationships, and resulting maps of predicted estimates are widely used to guide protected areas planning and monitor effectiveness to achieve conservation targets (Sanderson et al. 2002, Elith and Leathwick 2009, Franklin 2009, Veloz et al. 2015, Lecours 2017).

Although landcover is often the main explanatory covariate used for regional SDMs (e.g., Bustamante and Seoane 2004, Bellis et al. 2008, Atamian et al. 2010), topological and hydrological variables related to wetness may predict distribution equally well or even better than vegetation cover for some bird species (Barker et al. 2014), including the Olive-sided Flycatcher and Canada Warbler (Bale 2017). However, remote sensing products of vegetation cover tend to provide limited temporal replication, which is a concern when modeling habitat association of birds breeding in these dynamic landscapes (but see Hansen et al. 2013). Because hydrological variables are less prone to frequent disturbance effects than vegetation cover, they could be a particularly important tool to improve model accuracy for species associated with forested wetlands. High-quality remote sensing data classifying forested wetlands are scarce (but see Kreakie et al. 2012) and for regions in which they are available, accuracy can be highly variable because of the ephemeral nature of many types of wetland (Gómez-Rodríguez et al. 2008, Skagen et al. 2008). To our knowledge, the accuracy of available data products that can be used to identify forested wetlands in the Canadian Maritimes has not previously been tested in the context of SDMs.

To inform management of populations of these focal species in national parks, it is necessary to make accurate predictions while simultaneously achieving a resolution precise enough for management planning. The resolution of SDMs should ideally be determined by the size of forest stands in the region, the scale of habitat selection for the target organism, and the scale of management units (Sirkiä et al. 2012, Aguirre-Gutiérrez et al. 2013, Pradervand et al. 2014). In practice, most SDMs are constructed to reflect the resolution of available data layers 
(predictions can only be as fine as the coarsest layer of the input data) or limited computing power (Franklin 2009).

For these species in Canada, there are two national-scale SDMs that predict population density at a resolution of $1 \mathrm{~km} \times 1 \mathrm{~km}$ (Haché et al. 2014, Stralberg et al. 2015a). There are two regional scale SDMs, with one predicting population density in Alberta at $1 \mathrm{~km} \times 1 \mathrm{~km}$ resolution (Canada Warbler only; Ball et al. 2016) and one predicting species occurrence in Nova Scotia at $150 \mathrm{~m} \mathrm{x}$ $150 \mathrm{~m}$ resolution (Bale 2017). Although these are valuable for understanding provincial and national habitat associations and distributions, they are either (1) too coarse for management planning within national parks, or (2) lack complete coverage of maritime parks.

Our objectives were to (1) develop high-resolution (250 m x 250 m) SDMs predicting the population density of the Olive-sided Flycatcher and the Canada Warbler in four maritime national parks (Kouchibouguac, Fundy, Cape Breton Highlands, and Kejimkujik) and equally sized areas in the same ecoregions outside of these parks; (2) compare prediction accuracy of models using different products available to delineate wet forested stands (photo-interpreted wetlands, depth to water table, and the interaction between water table and forest cover); (3) evaluate the effects of anthropogenic disturbance on density estimates; and (4) compare population density estimates inside versus outside national parks.

\section{METHODS}

\section{Study area}

Of the total land base of Nova Scotia and New Brunswick, 7.9\% is within protected areas including national, provincial, and privately protected lands (Vankerham 2015), 19\% of which comprise the four national parks under consideration (Kouchibouguac, Fundy, Cape Breton Highlands, and Kejimkujik; Fig. 1). These parks are within in the Atlantic Maritime Ecozone, characterized by proximity to the Atlantic Ocean, creating a cool and moist climate (ESWG 1995). Prince Edward Island and part of the province of Québec are included in this ecozone, but they were excluded from our analysis because of a lack of available data layers. Atlantic maritime forests are predominantly composed of mixedwood stands of hemiboreal conifers and deciduous species, with the most common species being red spruce (Picea rubens), balsam fir (Abies balsamea), sugar maple (Acer saccharum), and yellow birch (Betula alleghaniensis). Black spruce (Picea mariana), white birch (Betula papyrifera), and other boreal tree species are less common (ESWG 1995). Nonforested areas in this region tend to comprise a patchwork of urbanization and agriculture, as well as coastal and highland environments (ESWG 1995). The four parks have a coastal component except Kejimkujik. A total of 7 ecoregions overlap these national parks (ESWG 1995; Fig. 1).

\section{Avian dataset}

The Boreal Avian Modelling Project (BAM) has compiled avian point count data in the boreal and hemiboreal regions of Canada and the U.S. (Barker et al. 2015). The BAM dataset contains data from over 1 million avian point count surveys conducted between 1990 and 2016 at over 250,000 locations (Barker et al. 2017). It includes data from long-term projects such as provincial breeding bird atlases (Bird Studies Canada 2017), the North American Breeding Bird Survey (USGS and ECCC 2018), and contributions from universities, governments, and industrial partners. These different projects used a wide range of sampling protocols, so data are harmonized through the application of statistical offsets to convert count data into density estimates (Barker et al. 2015). Specifically, avian data are standardized to control for the effects of survey protocols on detectability of each species, based on time of day, time of year, duration and radius of survey, and surrounding landcover types (Matsuoka et al. 2012, Sólymos et al. 2013, 2018). These standardized avian population density data have been used to predict range dynamics of passerines (Stralberg et al. 2017), climate change impacts on passerines (Stralberg et al. 2015a, b), regional population trends for species occurring in spruce-fir forests (Ralston et al. 2015), and Canada Warbler habitat needs in Alberta (Ball et al. 2016).

Fig. 1. Ecoregions of New Brunswick and Nova Scotia. Gray squares show randomly selected nonpark replicates used for comparison with the corresponding national park within the same ecoregion. Data source: CGDI National Frameworks Data.

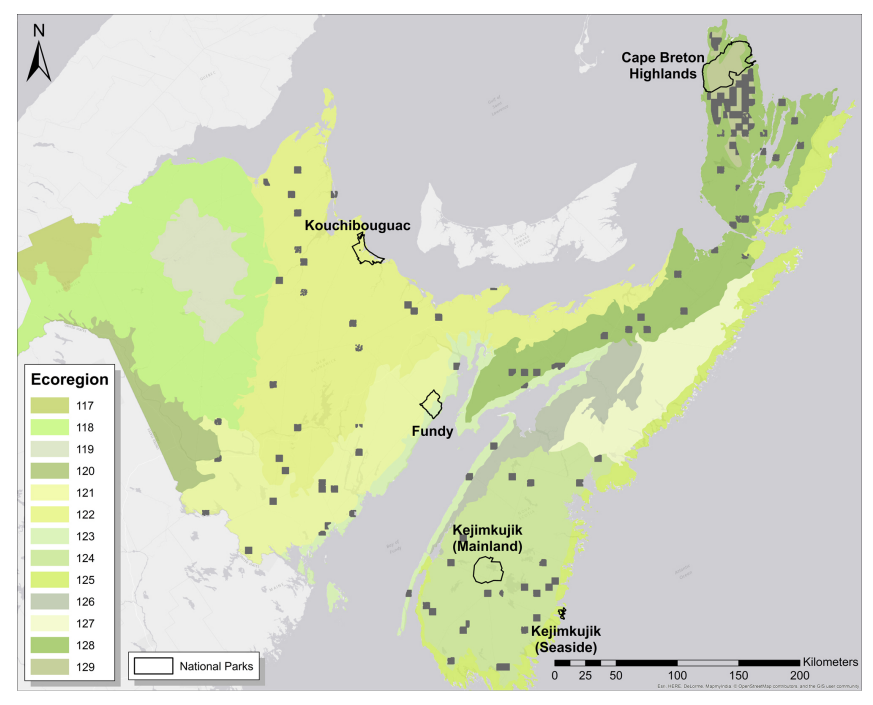

In our study area, the BAM project included 15,021 locations in which point counts were conducted between 1996 and 2013. Olivesided Flycatchers and Canada Warblers were detected at 801 and 658 locations, respectively (Appendix 1). To reflect local-level habitat attributes (hereafter "local buffer"), a different radius was used for each species. For the Canada Warbler, a $50 \mathrm{~m}$ radius $(0.79$ ha) was delineated around each point count location to reflect average territory size ( $\leq 1$ ha; Reitsma et al. 2010) and detection radius (60 m; Matsuoka et al. 2012). For the Olive-sided Flycatcher, a $100 \mathrm{~m}$ radius ( $3.14 \mathrm{ha}$ ) was used to reflect immediate habitat area around the nest, and larger detection radius for this species (123 m; Matsuoka et al. 2012). A larger buffer of $250 \mathrm{~m}$ radius (19.6 ha; hereafter "territory buffer") was created to capture habitat attributes within the territory of the Olive-sided Flycatcher (10-45 ha; Altman and Sallabanks 2012) and the often 
clustered territories (or neighborhoods) of Canada Warblers resulting from conspecific attraction (Hunt et al. 2017, Reitsma et al. 2018).

\section{Spatial covariates}

Spatial covariates were extracted at all point count locations (both presence and absence) using ESRI ArcGIS 10.2.2 (Esri 2014), PostGIS (Ramsey et al. 2011), R (R Core Team 2015), and/or Geospatial Modelling Environment (Beyer 2012). All GIS layers were projected in NAD83 (Canadian Spatial Reference System; Seely 2011, Government New Brunswick 2015, NRCAN 2019). A total of 20 covariates were extracted from 19 remote sensing products (Appendix 2), with vector data having a minimum mapping unit of $<50 \mathrm{~m}$, and cell size of raster data ranging from $10 \mathrm{~m} \times 10 \mathrm{~m}$ to $90 \mathrm{~m} \times 90 \mathrm{~m}$. The minimum resolution available for model predictions was $90 \mathrm{~m}$ x $90 \mathrm{~m}$, but because of computational limitations, all data layers were standardized to $250 \mathrm{~m} \times 250 \mathrm{~m}$ resolution for model predictions

\section{Wetness}

Three model subsets were used to test the effects of different methods used for delineating wet areas that could support forested wetlands, including (1) wetlands layers (WETLANDS), (2) depth to water table (WETNESS), and (3) WETNESS $\mathrm{x}$ forest cover (WETxFOR). For the WETLANDS subset, we used wetland layers classified from aerial photography in both provinces (minimum mapping unit $<30 \mathrm{~m}$ ) harmonized into five classes (tree, shrub, graminoid, aquatic, and water/exposed) based on the Canadian Wetlands Classification System (Warner and Rubec 1997; Appendix 2). The dominant wetland class type was extracted for each buffer.

For the WETNESS and WETxFOR subset, we used wet areas mapping (10 m resolution; Murphy et al. 2007, FWRC 2012) to measure average depth to water table (DTW) at both buffer sizes around each point count location. Depth to water table is a cartographic index derived from digital elevation models (Murphy et al. 2007). When compared with similar indices calculated using different algorithms (e.g., topographic wetness index, soil water index), DTW is more closely related to soil and vegetation type than the commonly used terrain wetness index, which is a function of elevation (Murphy et al. 2007, 2009, White et al. 2012) and performs better when used for modeling distribution of streams (White et al. 2012) and landbird species (Bale 2017). The DTW predicts small wetlands (i.e., $<1$ ha) that are usually not visible in aerial photographs (Murphy et al. 2007) and delineates wet areas under vegetation cover more accurately (White et al. 2012). We considered DTW $\leq 1 \mathrm{~m}$ to be areas which may support forested wetlands because these values correspond to field-measured depth to water table in forested wetlands (FWRC 2012). Other extracted covariates included the proportion of DTW $\leq 1 \mathrm{~m}$ and standard deviation of DTW within the territory buffer.

\section{Landcover and structure}

Forest cover information was derived from the Common Attribute Schema for Forest Resource Inventories (CASFRI; minimum mapping unit $<50 \mathrm{~m}$; Cumming et al. 2010, Cosco 2011), which combines provincial forest resource inventory databases into a comprehensive classification of attributes present across jurisdictions. From CASFRI, we extracted tree species composition (primary and secondary) and mean and standard deviation of canopy height and canopy closure within local and territory buffers. Percent tree species cover was converted into area $\left(\mathrm{m}^{2}\right)$ covered within both local and territory buffers. Tree species were also reclassed to genus (see https:/github.com/ borealbirds for model code).

\section{Landscape complexity and disturbance}

Mean landscape complexity was estimated for each territory buffer using a layer from Anderson et al. (2012), which estimates landscape complexity at three values (above average, average, or below average) based on combinations of three values: topography, elevation range, and moisture gradients. Landscape complexity was characterized as an index of the number and diversity of microsites available. The data layer was available at $90 \mathrm{~m}$ resolution.

Disturbance information was acquired from both the CASFRI and Human Footprint (HF) mapping (90 m resolution; Woolmer et al. 2008). Using CASFRI, we calculated the proportion of territory buffer affected by each of the following disturbance types: clearcuts, partial cuts, burns, slides, windfalls, and unspecified disturbances. This information did not include time since disturbance. The HF is an index of disturbance from 1-100 based on standardized measures of human population density, land transformation, accessibility, and electrical infrastructure (Sanderson et al. 2002). We calculated average HF index within each territory buffer. Distance to the nearest road (m) was calculated for each point count location using the National Road Network (GC and NRCAN 2015).

\section{Landscape connectedness and protected areas}

We calculated the mean index of landscape connectedness for each territory buffer based on a layer from Anderson and Clark (2012), who measured landscape connectedness at $90 \mathrm{~m}$ resolution as a continuous index based on the contiguity of cover types among what they considered natural ecosystems types. Finally, all point counts were intersected with park and protected area maps (including federal, provincial, and municipal protected areas), and classified as being on unprotected or protected lands.

\section{Models}

Rather than using a presence-absence species distribution modeling approach (Franklin 2009), we instead used count data to estimate population density. We used Poisson log-linear models to relate bird counts at locations to values of covariates at those locations. We used a model-building process based on a forward stepwise variable selection approach (also used in Haché et al. 2014, Ball et al. 2016, and Bayne et al. 2016). This method enters a set of competing covariates in stages to predict population density, and once the leading covariate is chosen at a given stage, it is entered into the next stage to compete against another set of covariates from which one is selected. This is repeated until the final stage is reached. This hierarchical model selection minimizes multicollinearity because all the covariates that were highly correlated $(r>0.7)$ entered the model at the same stage and only one of these covariates could be included in the final model.

We evaluated relative importance of covariates nested within eight stages based on a priori assumptions about the habitat selection of each species. We assumed that habitat selection-driven decisions at the regional scale were most related to proximate 
Table 1. Model subsets and descriptions of covariates used in stages one and two of hierarchical Poisson log-linear models of Olivesided Flycatcher and Canada Warbler density. All covariates were measured at either the local (L) buffer size (50 m for Canada Warbler, $100 \mathrm{~m}$ for Olive-sided Flycatcher), or the territory ( $\mathrm{T}$ ) buffer size ( $250 \mathrm{~m}$ for both species). Note: CASFRI = Common Attribute Schema for Forest Resource Inventories, DTW = depth to water table.

\begin{tabular}{|c|c|c|c|}
\hline Model Stage & Subset A: WETLANDS & Subset B: WETNESS & Subset C: WETxFOR \\
\hline 1. Wetness & $\begin{array}{l}\text { 1.0 Null } \\
\text { 1.1 Dominant wetland type (WET_TYPE (L)) } \\
\text { 1.2 Perimeter of wetland + stream length } \\
(\text { WET_LENGTH }(\mathrm{T})) \\
\text { 1.3 Proportion wetland (WET_PROP }(\mathrm{T}))\end{array}$ & $\begin{array}{l}\text { 1.0 Null } \\
\text { 1.1 Proportion of area with DTW classified } \\
\text { "wet" }(\leq 1 \mathrm{~m}) \text { (DTW_PROP }(\mathrm{L})) \\
\text { 1.2 Proportion with DTW classified "wet" } \\
(\leq 1 \mathrm{~m}) \text { (DTW_PROP }(\mathrm{T})) \\
\text { 1.3 Standard deviation of DTW } \\
\text { (DTW_STDEV }(\mathrm{T}))\end{array}$ & $\begin{array}{l}\text { 1-2.0 Null } \\
\text { 1-2.1 Tree species coverage (CASFRI) x } \\
\text { proportion of area with DTW classified } \\
\text { "wet" }(\leq 1 \mathrm{~m}) \text { (CASFRIxDTW_PROP } \\
(\mathrm{L})) \\
\text { 1-2.2 Tree species coverage (CASFRI) x } \\
\text { proportion of area with DTW classified } \\
\text { "wet" ( } \leq 1 \mathrm{~m} \text { ) (CASFRIxDTW_PROP } \\
(\mathrm{T}))\end{array}$ \\
\hline 2. Forest Cover & $\begin{array}{l}\text { 2.0 Null } \\
\text { 2.1 Tree species coverage (CASFRI (L)) } \\
\text { 2.2 -Tree species coverage (CASFRI (T)) }\end{array}$ & $\begin{array}{l}\text { 2.0 Null } \\
\text { 2.1 Tree species coverage (CASFRI (L)) } \\
\text { 2.2 -Tree species coverage (CASFRI (T)) }\end{array}$ & \\
\hline
\end{tabular}

factors (e.g., tree species, nest site availability, insect availability) and least related to ultimate factors (e.g., landscape composition, protection status of a site). Recognizing the importance of both types of factors, we ordered the following eight stages from proximate to ultimate covariates: (1) wetness; (2) forest cover; (3) forest structure; (4) landscape complexity; (5) anthropogenic disturbance; (6) distance from roads; (7) landscape connectivity; and (8) protection status. Stages one and two were merged for the WETxFOR subset, whereas variables in stage two remained the same for the two other model subsets (Table 1). For each model subset, covariates in stages three-eight were the same (Table 2). Consistent Akaike's information criterion (AIC; CAIC $=0.5 \mathrm{AIC}$ $+0.5 \mathrm{BIC}$, where $\mathrm{AIC}=$ Akaike's information criterion, $\mathrm{CAIC}=$ consistent Akaike's information criterion, and $\mathrm{BIC}=$ Bayesian information criterion) was used as our information criterion (Bozdogan 1987, Taper 2004).

We also evaluated models by calculating the coefficient of variation of population density estimates, as well as two goodness of fit measures: (1) area under the operating curve (AUC; Bradley 1997), a commonly used statistic that provides a measure of the likelihood that a randomly selected population density count has a higher suitability score than a randomly selected absence, and (2) directly comparing estimated mean population density with observed counts at our point count locations.

We used a bootstrap aggregation approach (Breiman 1996, Efron and Tibshirani 1998, Efron 2014), whereby the stage-wise modelbuilding process was repeated 240 times using bootstrapped runs of the data, with each bootstrap run randomly selecting $70 \%$ of the data. For each covariate, we reported the selection frequency based on that number of iterations (Burnham and Anderson 2002). The most frequently selected covariate at each stage (which could also include no covariate, i.e., null covariate) was carried over to the following stage and the process was repeated for all eight stages to produce a final model.

We present the selection frequency of the model terms divided by the number of bootstrap runs as a measure of variable importance (Appendix 3). We do not provide effect sizes because those would inaccurately represent the bootstrap averaging process (for example, when a term was not selected). Instead, we present marginal effect plots to capture how the different discrete and continuous covariates in our models affect bird density (Appendix 4). These plots show average change in the response averaged over all possible values of other covariates in the model (Avgar et al. 2017).

Table 2. Model subsets and descriptions of covariates used in stages three to eight of hierarchical Poisson log-linear models of Olive-sided Flycatcher and Canada Warbler density. All covariates were measured at either the local (L) buffer size $(50 \mathrm{~m}$ for Canada Warbler, $100 \mathrm{~m}$ for Olive-sided Flycatcher) or the territory (T) buffer size (250 $\mathrm{m}$ for both species). Note: CASFRI $=$ Common Attribute Schema for Forest Resource Inventories.

\begin{tabular}{|c|c|}
\hline Model Stage & $\begin{array}{l}\text { All subsets (WETLANDS, WETNESS, } \\
\text { WETxFOR) }\end{array}$ \\
\hline 3. Forest Structure & $\begin{array}{l}\text { 3.0 Null } \\
\text { 3.1 Mean canopy closure (CANCL_AV (L)) } \\
\text { 3.2 Mean canopy closure (CANCL_AV (T)) } \\
\text { 3.3 Standard deviation of canopy closure } \\
\text { (CANCL_STD (L)) } \\
\text { 3.4 Standard deviation of canopy closure } \\
\text { (CANCL_STD (T)) } \\
\text { 3.5 Mean canopy height (HT_AV (L)) } \\
\text { 3.6 Standard deviation of canopy height } \\
\text { (HT_STD (T)) }\end{array}$ \\
\hline 4. Land-scape & 4.0 Null \\
\hline Complexity & $\begin{array}{l}\text { 4.1 Mean landscape complexity } \\
(\text { COMPLEXITY (T)) }\end{array}$ \\
\hline 5. Disturbance & $\begin{array}{l}\text { 5.0 Null } \\
\text { 5.1 Leading CASFRI disturbances } \\
\text { (CASFRI_DIST (T)) } \\
\text { 5.2 Mean human footprint index } \\
\text { (FOOTPRINT }(\mathrm{T}))\end{array}$ \\
\hline 6. Road Distance & $\begin{array}{l}\text { 6.0 Null } \\
\text { 6.1 Distance from road (ROAD (L)) }\end{array}$ \\
\hline 7. Landscape & 7.0 Null \\
\hline Connectivity & 7.1 Mean connectivity index (CONNECT $(\mathrm{T})$ ) \\
\hline 8. Protection Status & $\begin{array}{l}\text { 8.0 Null } \\
\text { 8.1 Protected/unprotected (PROTECT (L)) }\end{array}$ \\
\hline
\end{tabular}


Prediction uncertainty (precision) was mapped as coefficient of variation derived from the standard error of the bootstrap predictions divided by the mean of the bootstrap predictions at any prediction point (240 runs). This process resulted in six SDMs (three subsets per species). Subsets were compared by examining frequency selection of covariates and consistent AIC. Model accuracy was assessed based on a graphical comparison of observed counts vs. expected values from bootstrap averaged predictions. We also calculated area under the receiver operator characteristic curve (AUC) as to a measure of how well models differentiated detections ( $>0$ count) from nondetections. The $\mathrm{R}$ scripts for the offsets and models are available at https://github. com/borealbirds

\section{Spatial predictions of density estimates}

Population density estimates for both species were generated across the study area, from which we generated population size estimates. This was achieved by establishing two grids across the study area. We applied a $250 \mathrm{~m}$ x $250 \mathrm{~m}$ grid across the study area ( $\sim 00$ cells per grid square; hereafter "prediction cells") with a point (hereafter "prediction point") generated at the centroid of each cell $(n=2,100,000)$. A total of 28,880 (ca. $1 \%$ ) prediction cells had their centroid within the four national parks: Cape Breton $(\mathrm{n}=15,447)$, Kouchibouguac $(\mathrm{n}=3410)$, Fundy $(\mathrm{n}=$ 3367), and Kejimkujik $(\mathrm{n}=6358)$.

We also developed a random sampling scheme to compare prediction cells inside and outside of parks. We established a 5 $\mathrm{km} \times 5 \mathrm{~km}$ grid across the study area and tallied the number of 5 $\mathrm{km} \times 5 \mathrm{~km}$ grid cells per park per ecoregion, where sums ranged from 7 (Fundy, ecoregion 123) to 38 (Cape Breton Highlands, ecoregion 129; Table 3). Then, we randomly sampled an equal number of $5 \mathrm{~km}$ x $5 \mathrm{~km}$ grid cells per ecoregion outside of park borders (Fig. 1; Table 3). In each nonpark grid cell, we randomly sampled the same number of prediction points as the equivalent grid square inside the corresponding park. For example, Fundy National Park contained seven grid squares in ecoregion 123, which were paired with seven randomly selected grid cells in ecoregion 123 outside of the national park. Within each pair, the same number of prediction points was used. For example, in one park grid square, only 350 prediction points fell within the park boundary. Thus, in the paired nonpark square, only 350 of a possible 400 prediction points were randomly chosen for sampling. If the paired grid square did not contain enough prediction points inside ecoregion 123 to meet this number, it was discarded, and another grid square chosen.

Prediction points were not sampled in the same spatial configuration within paired grid cells, which was impossible because of the different shapes of relevant borders. Because the prediction points are contiguous, a high level of spatial autocorrelation was to be expected within grid cells. However, we attempted to control for this by randomly selecting grid cells, which were generally not contiguous (Fig. 1).

Covariate information was extracted for each prediction point and the top model was used to generate mean and standard deviation of population density (males/ha) for each prediction point. These were summed to calculate population sizes for each park and ecoregion. We compared mean population density per grid cell between national parks and corresponding ecoregion areas outside the parks using t-tests.
Table 3. Grid squares ( $5 \mathrm{~km}$ x $5 \mathrm{~km}$ ) within Maritime national parks for comparison with grid cells randomly sampled elsewhere in the corresponding ecoregion.

\begin{tabular}{lccccc}
\hline \hline National Park & $\begin{array}{c}\text { Area } \\
\text { (ha) }\end{array}$ & Ecoregion & $\begin{array}{c}\text { Grid } \\
\text { squares } \\
\text { in park }\end{array}$ & $\begin{array}{c}\text { Total } \\
\text { ecoregion } \\
\text { area (\%) }\end{array}$ & $\begin{array}{c}\text { Percent of } \\
\text { ecoregion } \\
\text { in park }\end{array}$ \\
\hline Cape Breton & 96,663 & 128 & 36 & $1,551,054$ & $1.8 \%$ \\
Fundy & 21,051 & 121 & 12 & $1,317,982$ & $0.9 \%$ \\
Kejimkujik & 39,698 & 124 & 25 & $1,636,318$ & $2.4 \%$ \\
Mainland & & 123 & 9 & 481,733 & $2.0 \%$ \\
Kouchibouguac & 24,199 & 122 & 22 & $3,019,141$ & $0.8 \%$ \\
\hline
\end{tabular}

\section{RESULTS}

\section{Top models and variable selection}

All model subsets performed well, with predicted mean population density showing a close positive correlation to observed count (Fig. 2) and AUC values between 0.6-0.7. For Olive-sided Flycatcher, the WETxFOR subset was the most selected in $91 \%$ of the 240 bootstrapped runs, followed by WETLANDS and WETNESS at $7 \%$ and $2 \%$ of cases, respectively. For the Canada Warbler, the WETNESS subset was selected at $100 \%$ of the bootstrapped runs.

For the Olive-sided Flycatcher, covariates with the highest selection frequency at each stage (Appendix 3) for the top model were CASFRIxDTW_PROP territory (91\% of all runs), HT_STD territory (49\%), COMPLEXITY territory $(71 \%)$, FOOTPRINT territory (91\%), and CONNECT territory $(50 \%)$. Population density was highest in stands dominated by Picea spp. (but not Picea glauca), Picea mariana, and Abies spp., and lowest in stands dominated by Pinus spp. and deciduous trees. For all tree cover types, except Alnus spp., Olive-sided Flycatcher population density increased with a greater proportion of area buffer covered by forest with a corresponding DTW $\leq 1 \mathrm{~m}$. Population density increased with DTW_PROP at both the local and territory scales. Population density also increased with lower mean canopy closure and standard deviation, and lower mean height. FOOTPRINT and ROAD had negative effects, whereas population density increased with greater COMPLEXITY and CONNECTIVITY. With regard to PROTECTION, sites in protected areas showed slightly higher population density than areas outside the parks.

For the Canada Warbler top model, DTW_STD territory (100\%), CASFRI territory $(78 \%)$, CANCL_STD point $(60 \%)$, COMPLEXITY territory (96\%), FOOTPRINT territory $(94 \%)$, CONNECTIVITY (99.2\%), and PROTECTION (46\%) were the most frequently selected covariates (Appendix 3). Highest densities of Canada Warblers (Appendix 4) were predicted for stands with high proportions of Abies spp., Alnus spp., Picea spp., Picea mariana, and lowest population densities were reported for stands dominated by Acer spp., Larix spp., Picea glauca, and Pinus spp. Higher DTW_PROP point supported higher population densities of Canada Warbler, with a larger effect size at the territory scale (250 $\mathrm{m}$ radius). Lower DTW_STD values were 
Fig. 2. Goodness of fit measurements for species distribution models for the Olive-sided Flycatcher (OSFL) and Canada Warbler (CAWA) in New Brunswick and Nova Scotia across three subsets $(\mathrm{A}=$ WETLANDS, B = WETNESS, $\mathrm{C}=$ WETXFOR). Observed counts (X-axis) are compared to predicted mean population density (Y-axis), and Area Under the Curve (AUC) values reported for each model.
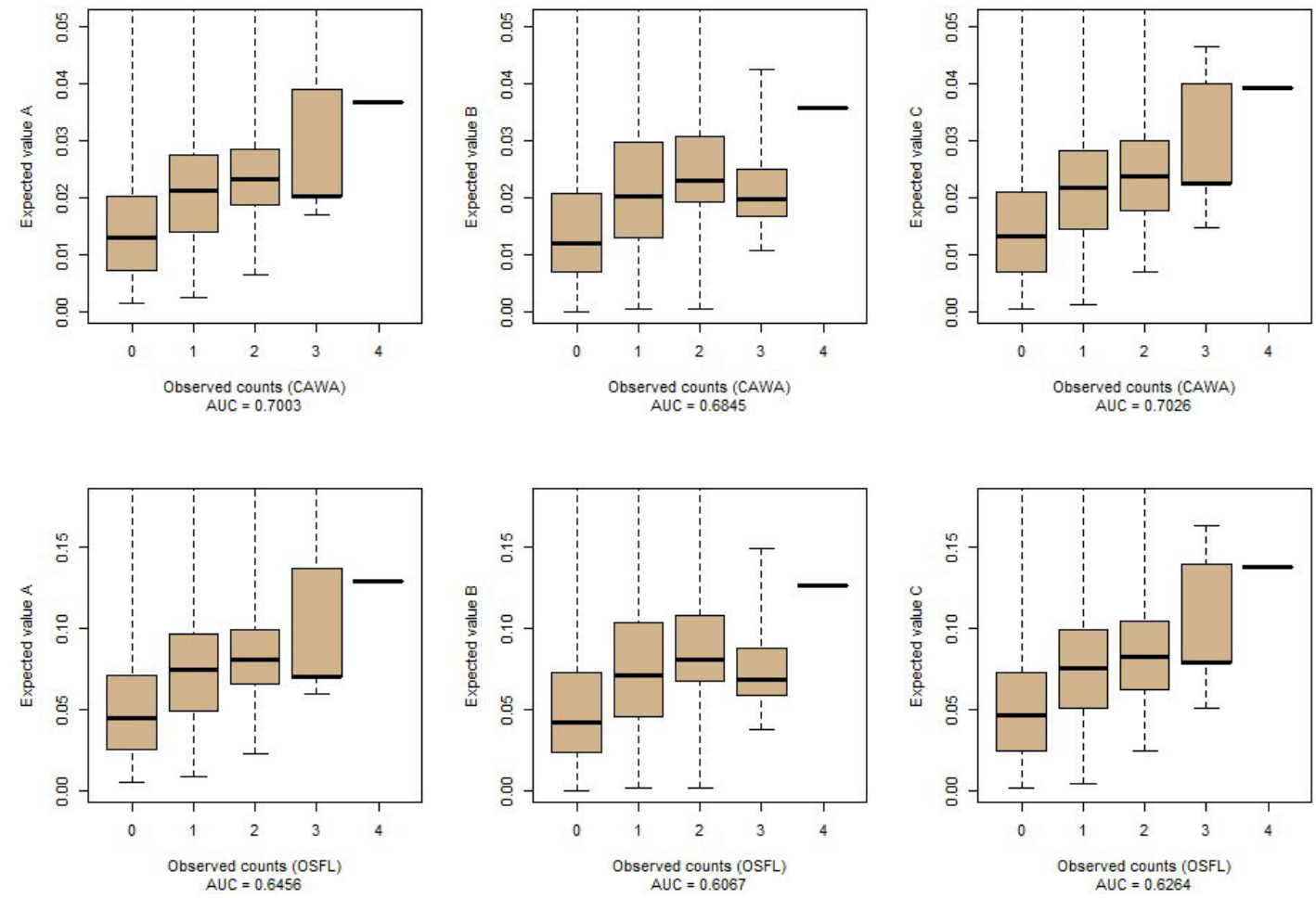

associated with higher population densities. Highest population density estimates were also associated with median values of CANCL_STD, HT_STD, and HT_AV at both scales. Higher COMPLEXITY and CONNECTEDNESS were predicted to support higher population density. Population density was predicted to be negatively impacted by FOOTPRINT and was lower closer to ROADS. When considering PROTECTION, population densities were slightly lower in protected areas. Scatterplots and boxplots detailing the effects of each final model covariate on estimated mean population density for both species can be found in Appendix 4.

\section{Population density and size estimates}

For both species, very little area in the parks was predicted to support high population densities (Appendix 5). In Fundy National Park (Fig. 3), which is composed mainly of a plateau, areas predicted to have high population density were largely restricted to ravines, particularly for the Olive-sided Flycatcher. The western side of Kejimkujik National Park was predicted to support higher population density than the eastern, whereas the interior of Cape Breton National Park showed higher population densities. Kouchibouguac Natural Park, largely represented by a maritime-influenced environment of beaches and saltmarshes, showed very low predicted population density throughout.

Olive-sided Flycatcher estimated mean population density in parks ranged from 0.011 males/ha (Kouchibouguac) to 0.014 males/ha (Cape Breton Highlands), whereas Canada Warbler predicted population density ranged from 0.016 males/ha (Kouchibouguac) to 0.045 males/ha (Cape Breton Highlands). Total estimated population size for the four national parks was 358 male Olive-sided Flycatchers and 1092 male Canada Warblers (Table 4).

Table 4. Predicted population density and population size of territorial males of Olive-sided Flycatcher and Canada Warbler in four Maritime national parks.

\begin{tabular}{|c|c|c|c|c|c|}
\hline \multirow[b]{2}{*}{ Park } & \multirow[t]{2}{*}{$\begin{array}{l}\text { Park } \\
\text { area } \\
\text { (ha) }\end{array}$} & \multicolumn{2}{|c|}{$\begin{array}{c}\text { Mean } \\
\text { population } \\
\text { density } \\
\text { (territorial } \\
\text { males/ha) }\end{array}$} & \multicolumn{2}{|c|}{$\begin{array}{l}\text { Predicted number of } \\
\text { territorial males }\end{array}$} \\
\hline & & OSFL & CAWA & OSFL & CAWA \\
\hline Kouchibouguac & 24,199 & 0.011 & 0.016 & 29 & 43 \\
\hline Fundy & 21,051 & 0.013 & 0.031 & 43 & 105 \\
\hline $\begin{array}{l}\text { Cape Breton } \\
\text { Highlands }\end{array}$ & 96,663 & 0.014 & 0.045 & 217 & 695 \\
\hline $\begin{array}{l}\text { Kejimkujik } \\
\text { (Mainland) }\end{array}$ & 39,698 & 0.011 & 0.038 & 67 & 242 \\
\hline Total & 401,506 & 0.011 & 0.031 & 358 & 1092 \\
\hline
\end{tabular}

Predicted population densities of Olive-sided Flycatcher inside parks were only significantly larger than outside the parks for ecoregions 123 (mean difference, mean $\Delta=0.007$ males $/$ ha, $\mathrm{n}=$ 
Fig. 3. Predicted mean density of territorial males/ha (left panels) and coefficient of variation (right panels) based on the top model for the Olive-sided Flycatcher and Canada Warbler in Fundy National Park, New Brunswick, Canada.

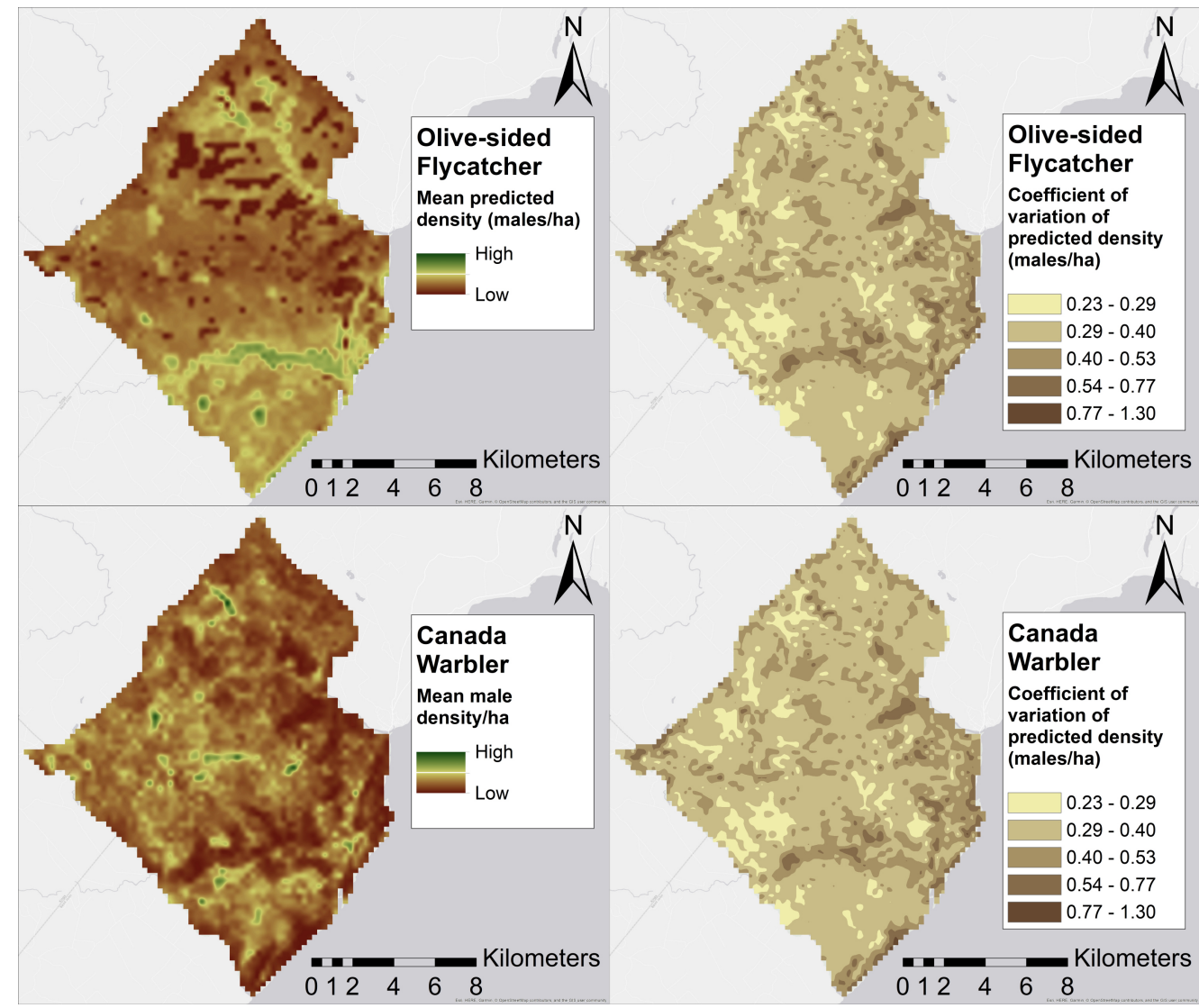

$7, p<0.001$ ) and 129 (mean $\Delta=0.002$ males/ha, $\mathrm{n}=38, p<0.001$; Fig. 4; Appendix 4). For Canada Warbler, predicted population densities were significantly higher in parks for ecoregion 123 (mean $\Delta=0.003$ males/ha, $\mathrm{n}=7, p<0.001$ ), but significantly lower in parks for ecoregions 122 (mean $\Delta=0.024$ males $/ \mathrm{ha}, \mathrm{n}=$ $19, p<0.001$ ) and 129 (mean $\Delta=0.016, \mathrm{n}=28, p<0.001$; Fig. 4, Appendix 4).

\section{DISCUSSION}

We used the largest available avian point count dataset for New Brunswick and Nova Scotia to generate SDMs to estimate population density and population size of two landbird species at risk in national parks. We evaluated model prediction accuracy using different approaches to delineate wet forest and quantify the effects of anthropogenic disturbance on population density. Finally, we compared population density estimates in national parks versus those from other areas in the same ecoregions.

All the covariates selected in the top model for both species and corresponding relationships are consistent with known habitat associations on their breeding ranges (Reitsma et al. 2010, Altman and Sallabanks 2012). Higher Olive-sided Flycatcher population densities were predicted in wet forest stands, especially at the territory scale. Population densities were also higher where trees are patchily distributed based on coefficient for canopy cover and height, as well as in more complex landscapes. These results could also reflect this species' preference for edges because they are known to nest in emergent trees alongside wetlands, as well as barrens, burns, and cuts (Altman and Sallabanks 2012).

Higher Canada Warbler population densities in mixedwood stands are consistent with results from other studies conducted on the eastern portion of the range (Hallworth et al. 2008a, b). In southwest Nova Scotia, Canada Warblers are known to nest in stands dominated by Acer rubrum, with a lesser component of Picea mariana (Westwood 2016), which contrasts with the negative association with large proportions of Acer spp. reported in our study. This may reflect within-region differences in the tree composition of forested wetlands. Another explanation may be the nature of the small territories that Canada Warblers occupy. Individual effects of tree cover covariates were stronger at the local scale, corresponding to habitat within the Canada Warbler's immediate territory (approx. 1 ha; Reitsma et al. 2018). Complexity was positively associated with Canada Warbler density. This is consistent with reported species' needs for a high diversity of trees, shrubs, and forest floor microsites for nesting, foraging, and territorial displays (Reitsma et al. 2010). The importance of complexity at larger spatial scales (indicative of a diversity of microsites) should not be confused with habitat fragmentation, which may have negative effects on Canada Warbler (Hunt et al. 2017). 
Fig. 4. Mean population density (males/ha) of Olive-sided Flycatcher (OSFL) and Canada Warbler (CAWA) in national parks and surrounding randomly selected areas outside of national parks of the same size in New Brunswick and Nova Scotia.
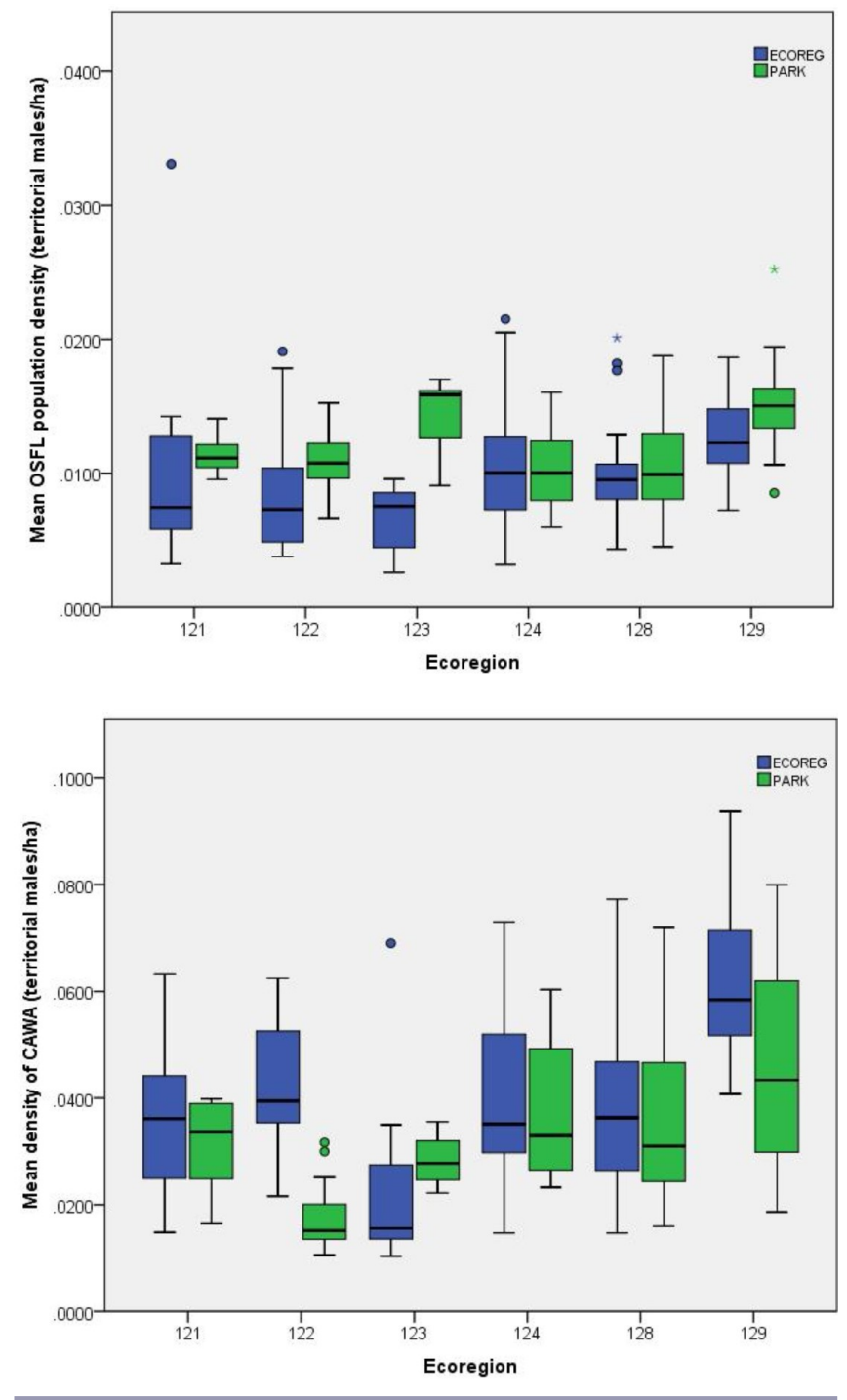

For both species, model subsets using depth to water table (DTW) mapping yielded higher selection frequency than those using wetlands mapping or forest cover alone. Consistent with our results, Kreakie et al. (2012) found that prediction accuracy of waterfowl population density derided from DTW-based SDMs was greater than those based on wetland mapping derived from satellite imagery. Bale (2017) found that results from presenceonly SDMs using DTW for these species and another landbird species at risk, the Rusty Blackbird (Euphagus carolinus), had higher prediction accuracy than those using topographic wetness index. These results and those from this study suggest the potential usefulness of DTW over other measures available to model densities of species associated with forested wetlands, particularly if an interaction effect is included for forest cover. This is likely important for species that are nesting in stands in which saturated soils may be concealed from aerial imagery by tree cover.

\section{The role of national parks in regional protection of species at risk}

Population densities of both Canada Warbler and Olive-sided Flycatcher showed negative associations with human footprint and roads, and positive associations with connectedness and complexity. This suggests these species at risk are sensitive to anthropogenic disturbance and habitat fragmentation. For a review of the known effects of timber harvesting on Canada Warbler habitat, see Harding et al. (2017), Hunt et al. (2017), and Westwood et al. (2017). Although parks supported significantly higher population densities of Olive-sided Flycatchers in two of six ecoregions, they only supported significantly higher population densities of Canada Warbler in one ecoregion and significantly lower in two another ecoregions, suggesting that national parks alone do not confer a substantial benefit to populations of these species under current land-use regimes.

Haché et al. (2014), using the BAM dataset and the same analytical approach, estimated the total number of territorial Olive-sided Flycatcher and Canada Warbler males in New Brunswick and Nova Scotia at approximately 80,000 and 463,000, respectively. When comparing our predicted population sizes in national parks to the BAM regional estimates, national parks would include less than $0.01 \%$ of the populations for both species, which is lower than expected given that these national parks cover $1.4 \%$ of the study area and comprise mostly forest habitat. This may reflect the limited ability of national models to capture important regional processes at the proper spatial scale $(<6.25$ ha). Alternatively, national parks in this region may be capturing much less than a representative proportion of the regional population.

\section{Limitations and next steps}

Our models did not include measures of climate, which are commonly used at larger spatial extents (e.g., Lawler et al. 2013, Stralberg et al. 2015b). Although vegetation is likely a more important driver of local variation than climate at spatial extent of our study area (Forsman and Mönkkönen 2003), climate should be considered when forecasting future habitat suitability because birds in particular have experienced recent distribution shifts due to climate change (e.g., Nogués-Bravo et al. 2012). These changes are expected to continue (Cumming et al. 2014, Stralberg et al. 2015a). Our models also averaged over 17 years of avian point count data during which time land cover likely changed. However, there is inadequate temporal replication for land-cover data in this region to test for temporal effects.

Once updated geospatial data and processing power becomes available, future work should extend our SDMs to fully cover New Brunswick and Nova Scotia. Because many of the geospatial layers we used were greater than five years old, and the rapid declines of these species as well as the strongly anticipated effects of climate change (Stralberg et al. 2015a), more recent data will be important to improve prediction accuracy. We also expected that these parks would contain a greater proportion of the populations based on regional models, because national models 
may have been biased toward predicting higher population densities in regions with much greater numbers of bird observations (central and north-western Canada; Haché et al. 2014).

National parks, although covering a small portion of the land base in Nova Scotia and New Brunswick, serve an important role in protecting species at risk (Deguise and Kerr 2006). Under the National Accord for the Protection of Species at Risk (GC 2014), Parks Canada is involved with the development and support of recovery strategies and implementation of recovery actions on their lands. Although the total number of individuals protected will not be enough to slow population declines at a level to support regional delisting (COSEWIC 2011), our models can be used to inform management planning in Maritime national parks to steward and recover existing populations. To ensure the continued effective protection of a maximum number of species at risk within national parks, it will be important that a coordinated, multijurisdictional approach can be undertaken to recover these and other species of conservation concern.

Responses to this article can be read online at:

http://www.ace-eco.org/issues/responses.php/1359

\section{Acknowledgments:}

This publication is a contribution of the Boreal Avian Modelling (BAM) Project, an international research collaboration targeting the ecology, management, and conservation of boreal birds. We acknowledge BAM's members, avian and biophysical Data Partners, and funding agencies (including Environment and Climate Change Canada and the U.S. Fish \& Wildlife Service), listed in full at http:// www.borealbirds.calindex.phplacknowledgements. The BAM project's database includes Breeding Bird Survey data and provincial Breeding Bird Atlas data, and we acknowledge the hundreds of skilled volunteers in Canada who have participated in these surveys over the years, and those who have served as provincial or territorial coordinators for the BBS. AW was supported by an NSERC PGS$D$ and Parks Canada for this work. We also thank Mélina Houle for providing CASFRI data intersections. We thank Nicole Barker, Karen Beazley, Peter Bush, and Francisco Dénes for their editorial support on earlier drafts of this work. Finally, we thank the two anonymous reviewers and the subject editor for their feedback in improving this manuscript.

\section{LITERATURE CITED}

Aguirre-Gutiérrez, J., L. G. Carvalheiro, C. Polce, E. E. van Loon, N. Raes, M. Reemer, and J. C. Biesmeijer. 2013. Fit-for-purpose: species distribution model performance depends on evaluation criteria - Dutch Hoverflies as a case study. PloS one 8:e63708. 10.1371/journal.pone.0063708. http://dx.doi.org/10.1371/journal. pone. 0063708

Altman, B., and R. Sallabanks. 2012. Olive-sided Flycatcher (Contopus cooperi). In A. Poole, editor. The birds of North America online. Cornell Lab of Ornithology, Ithica, New York, USA. [online] URL: https://birdsna.org/Species-Account/bna/species/ olsfly/introduction http://dx.doi.org/10.2173/bna.502
Amos-Binks, L. J., D. A. MacLean, J. S. Wilson, and R. G. Wagner. 2010. Temporal changes in species composition of mixedwood stands in northwest New Brunswick: 1946-2008. Canadian Journal of Forest Research 40:1-12. http://dx.doi. org/10.1139/X09-162

Anderson, M. G., and M. Clark. 2012. Modeling landscape permeability: a description of two methods to model landscape permeability. The Nature Conservancy - Eastern Conservation Science, Boston, Massachusetts, USA. [online] URL: https:// www.conservationgateway.org/ConservationByGeography/NorthAmerica/ UnitedStates/edc/Documents/ModelingLandscapePermeability.pdf

Anderson, M. G., M. Clark, and A. O. Sheldon. 2012. Resilient sites for terrestrial conservation in the Northeast and Mid-Atlantic region. The Nature Conservancy - Eastern Conservation Science, Boston, Massachusetts, USA. [online] URL: https://rcngrants. org/sites/default/files/final_reports/Resilient-Sites-for-Species-Conservation (1).pdf

Atamian, M. T., J. S. Sedinger, J. S. Heaton, and E. J. Blomberg. 2010. Landscape-level assessment of brood rearing habitat for Greater Sage-Grouse in Nevada. Journal of Wildlife Management 74:1533-1543. http://dx.doi.org/10.1111/j.1937-2817.2010.tb01281. $\mathrm{x}$

Avgar, T., S. R. Lele, J. L. Keim, and M. S. Boyce. 2017. Relative selection strength: quantifying effect size in habitat- and stepselection inference. Ecology and Evolution 7:5322-5330. http://dx. doi.org/10.1002/ece3.3122

Bale, S. 2017. Building an arc in the Anthropocene: applying principles of environmental resilience to improve single-species conservation planning in an era of climate change. Thesis. Dalhousie University, Halifax, Nova Scotia, Canada. [online] URL: https://dalspace.library.dal.ca/handle/10222/73520

Ball, J. R., P. Sólymos, F. K. A. Schmiegelow, S. Hache, J. Schieck, and E. Bayne. 2016. Regional habitat needs of a nationally listed species, Canada Warbler (Cardellina canadensis), in Alberta, Canada. Avian Conservation and Ecology 11(2):10. http://dx.doi. org/10.5751/ACE-00916-110210

Barker, N. K. S., E. Bayne, S. G. Cumming, F. Dénes, T. Fontaine, S. Haché, M. Houle, E. Knight, L. Leston, C. L. Mahon, S. M. Matsuoka, F. K. A. Schmiegelow, P. Sólymos, S. J. Song, T. Stehelin, D. Stralberg, A. Suárez-Esteban, J. D. Toms, S. L. Van Wilgenburg, and A. R. Westwood. 2017. Annual report: April 2016-March 2017. Boreal Avian Modelling Project, Edmonton, Alberta, Canada. [online] URL: http://www.borealbirds.ca/files/ Technical_Reports/BAM.AnnualReport.2016_17.V09_forprint.pdf

Barker, N. K. S., S. G. Cumming, and M. Darveau. 2014. Models to predict the distribution and abundance of breeding ducks in Canada. Avian Conservation and Ecology 9(2):7. http://dx.doi. org/10.5751/ACE-00699-090207

Barker, N. K. S., P. C. Fontaine, S. G. Cumming, D. Stralberg, A. Westwood, E. M. Bayne, P. Sólymos, F. K. A. Schmiegelow, S. J. Song, and D. J. Rugg. 2015. Ecological monitoring through harmonizing existing data: lessons from the boreal avian modelling project. Wildlife Society Bulletin 39:480-487. http://dx. doi.org/10.1002/wsb.567 
Bayne, E., L. Leston, C. L. Mahon, P. Sólymos, C. Machtans, H. Lankau, J. R. Ball, S. L. Van Wilgenburg, S. G. Cumming, T. Fontaine, F. K. A. Schmiegelow, and S. J. Song. 2016. Boreal bird abundance estimates within different energy sector disturbances vary with point count radius. Condor 118:376-390. http://dx.doi. org/10.1650/CONDOR-15-126.1jyl

Becker, D. A., P. Bohall, and P. D. Keyser. 2012. Canada Warbler use of harvested stands following timber management in the southern portion of their range. Forest Ecology and Management 276:1-9. http://dx.doi.org/10.1016/j.foreco.2012.03.018

Bellis, L. M., A. M. Pidgeon, V. C. Radeloff, V. St-Louis, J. L. Navarro, and M. B. Martella. 2008. Modeling habitat suitability for Greater Rheas based on satellite image texture. Ecological Applications 18:1956-1966. http://dx.doi.org/10.1890/07-0243.1

Berry, A., A. Lavers, and L. Mitchell. 2018. Old forest policy and regulatory frameworks in Nova Scotia and New Brunswick with a comparison to British Columbia. Forestry Chronicle 94:13-19. http://dx.doi.org/10.5558/tfc2018-003

Betts, M. G., S. E. Franklin, and R. G. Taylor. 2003. Interpretation of landscape pattern and habitat change for local indicator species using satellite imagery and geographic information system data in New Brunswick, Canada. Canadian Journal of Forest Research 33:1821-1831. http://dx.doi.org/10.1139/X03-104

Beyer, H. L. 2012. Geospatial modelling environment. Version 0.7.3.0. Spatial Ecology. [online] URL: http://www.spatialecology. com/gme

Bird Studies Canada. 2017. National breeding bird atlas program. Bird Studies Canada, Port Rowan, Ontario, Canada. [online] URL: http://www.birdscanada.org/volunteer/atlas/

Bozdogan, H. 1987. Model selection and Akaike's information criterion (AIC): the general theory and its analytical extensions. Psychometrika 52:345-370. http://dx.doi.org/10.1007/BF02294361

Bradley, A. P. 1997. The use of the area under the ROC curve in the evaluation of machine learning algorithms. Pattern Recognition 30:1145-1159. http://dx.doi.org/10.1016/S0031-3203 (96)00142-2

Breiman, L. 1996. Bagging predictors. Machine Learning 24:123-140. http://dx.doi.org/10.1007/BF00058655

Burnham, K. P., and D. R. Anderson. 2002. Model selection and multimodel interference: a practical information-theoretic approach. Second edition. Springer, New York, New York, USA.

Bustamante, J., and J. Seoane. 2004. Predicting the distribution of four species of raptors (Aves: Accipitridae) in southern Spain: statistical models work better than existing maps. Journal of Biogeography 31:295-306. http://dx.doi.org/10.1046/ j.0305-0270.2003.01006.x

Canada Warbler International Conservation Initiative (CWICI). 2016. CWICI roundtable discussion. Conference proceedings. Canada Warbler International Conservation Initiative Meeting, North American Ornithological Congress, Ottawa, Ontario, Canada.

Canadian Council of Forest Ministers (CCFM). 2019. Net merchantable volume of roundwood harvested by jurisdiction, tenure, category and species group. Canadian Council of Forest Ministers, National Forestry Database, Ottawa, Ontario, Canada. [online] URL: http://nfdp.ccfm.org/en/data/harvest. php

Canadian Geospatial Data Infrastructure. 2017. A national ecological framework for Canada. Government of Canada, Ottawa, Ontario, Canada. [online] URL: http://sis.agr.gc.ca/ cansis/nsdb/ecostrat/gis_data.html

Céspedes, L. N., and N. J. Bayly. 2018. Over-winter ecology and relative density of Canada Warbler Cardellina canadensis in Colombia: the basis for defining conservation priorities for a sharply declining long-distance migrant. Bird Conservation International :1-17. http://dx.doi.org/10.1017/S0959270918000229

Committee on the Status of Endangered Wildlife in Canada (COSEWIC). 2011. COSEWIC's assessment process and criteria. Committee on the Status of Endangered Wildlife in Canada, Ottawa, Ontario, Canada. [online] URL: https://www.canada.ca/ content/dam/eccc/migration/cosewic-cosepac/94d0444d-369c-49eda586-ec00c3fef69b/assessment_process_and_criteria_e.pdf

Cosco, J. 2011. Common attribute schema (CAS) for forest inventories across Canada. Boreal Avian Modelling Project; Canadian BEACONs Project, Edmonton, Alberta, Canada. [online]URL:http://www.borealbirds.ca/files/CAS_Document_Final_Mar_2010_ALL_APPENDICES.pdf

Cumming, S. G., F. K. A. Schmiegelow, E. M. Bayne, and S. J. Song. 2010. Canada's forest resource inventories: compiling a tool for boreal ecosystems analysis and modelling. Version 1.0. Canadian BEACONs Project; Boreal Avian Modelling Project, Edmonton, Alberta, Canada. [online] URL: http://www. borealbirds.ca/files/technical_reports/CAS_Backgrounder_v1.0.pdf

Cumming, S. G., D. Stralberg, K. L. Lefevre, P. Sólymos, E. M. Bayne, S. Fang, T. Fontaine, D. Mazerolle, F. K. A. Schmiegelow, and S. J. Song. 2014. Climate and vegetation hierarchically structure patterns of songbird distribution in the Canadian boreal region. Ecography 37:137-151. http://dx.doi.org/10.1111/ j.1600-0587.2013.00299.X

Deguise, I. E., and J. T. Kerr. 2006. Protected areas and prospects for endangered species conservation in Canada. Conservation Biology 20:48-55. http://dx.doi.org/10.1111/j.1523-1739.2005.00274. $\mathrm{X}$

de Lima Pereira, K. D. 2016. Olive-sided Flycatcher, Contopus cooperi, in the Cerrado biome, and a review of records in Brazil. Revista Brasileira De Ornitologia 24:46-52. [online] URL: http:// www.revbrasilornitol.com.br/BJO/article/view/1145

Ecological Stratification Working Group (ESWG). 1995. A national ecological framework for Canada. Agriculture and AgriFood Canada, Research Branch, Centre for Land and Biological Resources Research and Environment Canada, State of the Environment Directorate, Ecozone Analysis Branch, Ottawa/ Hull, Ontario, Canada. [online] URL: http://sis.agr.gc.ca/cansis/ nsdb/ecostrat/index.html

Efron, B. 2014. Estimation and accuracy after model selection. Journal of the American Statistical Association 109:991-1007. http://dx.doi.org/10.1080/01621459.2013.823775 
Efron, B., and R. J. Tibshirani. 1998. An introduction to the bootstrap. Chapman and Hall/CRC, Boca Raton, Florida, USA.

Elith, J., and J. Leathwick. 2009. The contribution of species modelling to conservation priorization. Pages 70-93 in A. Moilanen, K. A. Wilson, and H. P. Possingham, editors. Spatial conservation prioritization: quantitative methods and computational tools. Oxford University Press, Oxford, UK.

Environment and Climate Change Canada (ECCC). 2017. North American breeding bird survey - Canadian trends website, Dataversion 2015: trend results for Olive-sided Flycatcher. Environment and Climate Change Canada, Gatineau, Quebec, Canada. [online] URL: https://wildlife-species.canada.ca/breeding-birdsurvey-results/P004/A001/?lang $=\mathrm{e} \& \mathrm{~m}=\mathrm{s} \& \mathrm{r}=\mathrm{OSFL} \& \mathrm{p}=\mathrm{S}$

Environment Canada (EC). 2015. Recovery strategy for Olivesided Flycatcher (Contopus cooperi) in Canada (proposed). Environment Canada, Ottawa, Ontario, Canada. [online] URL: https://www.registrelep-sararegistry.gc.ca/virtual_sara/files/plans/ rs_olive-sided $\% 20$ flycatcher_e_proposed.pdf

Environment Canada (EC). 2016. Recovery strategy for Canada Warbler (Cardellina canadensis) in Canada. Environment Canada, Ottawa, Ontario, Canada. [online] URL: https://www. sararegistry.gc.ca/virtual_sara/files/plans/rs_canada $\% 20$ warbler_e_final. pdf

Esri, Inc. 2014. ArcGIS for desktop 10.2.2. Esri, Inc., Toronto, Ontario, Canada. [online] URL: https://www.esri.com/en-us/ arcgis/about-arcgis/overview

Forest Watershed Research Centre (FWRC). 2012. Nova Scotia wet areas mapping and flow accumulation channel. Forest Watershed Research Centre, Fredericton, New Brunswick, Canada. [online] URL: http://novascotia.ca/natr/forestry/gis/ wamdownload.asp

Forsman, J. T., and M. Mönkkönen. 2003. The role of climate in limiting European resident bird populations. Journal of Biogeography 30:55-70. http://dx.doi.org/10.1046/j.1365-2699.2003.00812. $\mathrm{x}$

Franklin, J. 2009. Mapping species distributions: spatial inference and prediction. Cambridge University Press, Cambridge, UK. http://dx.doi.org/10.1017/CBO9780511810602

Gómez-Rodríguez, C., J. Bustamante, S. Koponen, and C. DíazPaniagua. 2008. High-resolution remote-sensing data in amphibian studies: identification of breeding sites and contribution to habitat models. Herpetological Journal 18:103-113. [online] URL: http://webspersoais.usc.es/export9/ sites/persoais/persoais/andres.baselga/pdfs2/Gomez-

Rodriguez_et_al_2008_Herp_Journ.pdf

Government of Canada (GC). 2002. Species at Risk Act. S.C. 2002, c.29. Government of Canada, Ottawa, Ontario, Canada. [online] URL: https://laws.justice.gc.ca/eng/acts/S-15.3/

Government of Canada (GC). 2014. Protection of species at risk: federal, provincial and territorial accord. Government of Canada, Ottawa, Ontario, Canada. [online] URL: https://www.canada.ca/ en/environment-climate-change/services/species-risk-act-accordfunding/protection-federal-provincial-territorial-accord.html
Government of Canada (GC). 2017. National parks general regulations. Government of Canada, Ottawa, Ontario, Canada. [online] URL: https://laws-lois.justice.gc.ca/eng/regulations/ sor-78-213/index.html

Government of Canada (GC), and Natural Resources Canada (NRCAN). 2015. National road network. Government of Canada and Natural Resources Canada, Earth and Sciences Sector, Canada Centre for Mapping and Earth Observation, Government of Canada, Ottawa, Ontario, Canada. [online] URL: https:/open.canada.ca/data/en/dataset/3d282116-e556-400c-9306ca1a3cada $77 \mathrm{f}$

Government of New Brunswick. 2015. Surveys Act (RSNB 2011, c 226). Government of New Brunswick, Fredericton, New Brunswick, Canada. [online] URL: https://www.canlii.org/en/nb/ laws/stat/rsnb-2011-c-226/latest/rsnb-2011-c-226.html

Guisan, A., R. Tingley, J. B. Baumgartner, I. Naujokaitis-Lewis, P. R. Sutcliffe, A. I. T. Tulloch, T. J. Regan, L. Brotons, E. McDonald-Madden, C. Mantyka-Pringle, T. G. Martin, J. R. Rhodes, R. Maggini, S. A. Setterfield, J. Elith, M. W. Schwartz, B. A. Wintle, O. Broennimann, M. Austin, S. Ferrier, M. R. Kearney, H. P. Possingham, and Y. M. Buckley. 2013. Predicting species distributions for conservation decisions. Ecology Letters 16:1424-1435. http://dx.doi.org/10.1111/ele.12189

Haberski, A., M. McHugh, J. Hagelin, and D. Sikes. 2016. An overview of ongoing research: arthropod abundance and diversity at Olive-sided Flycatcher nest sites in interior Alaska. AKES Newsletter 9:29-31. [online] URL: http://www.akentsoc.org/doc/ AKES_newsletter_2016_n1_a11.pdf

Haché, S., P. Solymos, T. Fontaine, E. M. Bayne, S. G. Cumming, F. Schmiegelow, and D. Stralberg. 2014. Analyses to support critical habitat identification for Canada Warbler, Olive-sided Flycatcher, and Common Nighthawk, final report 1. Boreal Avian Modelling Project, Edmonton, Alberta, Canada. [online] URL: http://www.borealbirds.ca/files/Technical_Reports/Hacheetal2014. pdf

Hallworth, M., P. M. Benham, J. D. Lambert, and L. Reitsma. 2008a. Canada warbler (Wilsonia canadensis) breeding ecology in young forest stands compared to a red maple (Acer rubrum) swamp. Forest Ecology and Management 255:1353-1358. http:// dx.doi.org/10.1016/j.foreco.2007.10.045

Hallworth, M., A. Ueland, E. Anderson, J. D. Lambert, and L. Reitsma. 2008b. Habitat selection and site fidelity of Canada Warblers (Wilsonia canadensis) in Central New Hampshire. Auk 125:880-888. http://dx.doi.org/10.1525/auk.2008.07115

Hansen, M. C., P. V. Potapov, R. Moore, M. Hancher, S. A. Turubanova, A. Tyukavina, D. Thau, S. V. Stehman, S. J. Goetz, T. R. Loveland, A. Kommareddy, A. Egorov, L. Chini, C. O. Justice, and J. R. G. Townshend. 2013. High-resolution global maps of 21st-Century forest cover change. Science 342:850-853. http://dx.doi.org/10.1126/science.1244693

Harding, C., L. Reitsma, and J. D. Lambert. 2017. Guidelines for managing Canada Warbler habitat in the Northeast and MidAtlantic regions. High Branch Conservation Services, Hartland, Vermont, USA. [online] URL: http://highbranchconservation. 
com/wp-content/uploads/2017/02/Guidelines-for-Managing-CanadaWarbler-Habitat-in-the-Northeast-and-Mid-Atlantic-Regions-2017. pdf

Hunt, A. R., E. M. Bayne, and S. Haché. 2017. Forestry and conspecifics influence Canada Warbler (Cardellina canadensis) habitat use and reproductive activity in boreal Alberta, Canada. Condor 119:832-847. http://dx.doi.org/10.1650/CONDOR-17-35.1

Kreakie, B. J., Y. Fan, and T. H. Keitt. 2012. Enhanced migratory waterfowl distribution modeling by inclusion of depth to water table data. PloS one 7:e30142. http://dx.doi.org/10.1371/journal. pone. 0030142

Lawler, J. J., A. S. Ruesch, J. D. Olden, and B. H. McRae. 2013. Projected climate-driven faunal movement routes. Ecology Letters 16:1014-1022. http://dx.doi.org/10.1111/ele.12132

Lecours, V. 2017. On the use of maps and models in conservation and resource management (warning: results may vary). Frontiers in Marine Science 4:288. http://dx.doi.org/10.3389/fmars.2017.00288

Leverington, F., K. L. Costa, H. Pavese, A. Lisle, and M. Hockings. 2010. A global analysis of protected area management effectiveness. Environmental Management 46:685-698. http://dx. doi.org/10.1007/s00267-010-9564-5

Matsuoka, S. M., E. M. Bayne, P. Sólymos, P. C. Fontaine, S. G. Cumming, F. K. A. Schmiegelow, and S. J. Song. 2012. Using binomial distance-sampling models to estimate the effective detection radius of point-count surveys across boreal Canada. Auk 129:268-282. http://dx.doi.org/10.1525/auk.2012.11190

Matsuoka, S. M., P. Sólymos, T. Fontaine, and E. Bayne. 2011. Roadside surveys of boreal forest birds: how representative are they and how can be improve current sampling? Boreal Avian Modelling Project, Edmonton, Alberta, Canada. [online] URL: http://www. borealbirds.ca/files/BAM_Report_on_Roadside_Survey_Bias_for_EC. pdf

Miller, N. A. 1999. Landscape and habitat predictors of Canada Warbler (Wilsonia Canadensis) and Northern Waterthrush (Seiurus noveboracensis) occurrence in Rhode Island. Thesis. Department of Natural Resources, University of Rhode Island, Kingston, Rhode Island, USA. [online] URL: https:// digitalcommons.uri.edu/cgi/viewcontent.cgi?referer=https://www. google.com $/ \&$ httpsredir $=1 \&$ article $=1603 \&$ context $=$ theses

Mosseler, A., J. A. Lynds, and J. E. Major. 2003. Old-growth forests of the Acadian Forest Region. Environmental Reviews 11: S47-S77. http://dx.doi.org/10.1139/a03-015

Murphy, P. N. C., J. Ogilvie, and P. Arp. 2009. Topographic modelling of soil moisture conditions: a comparison and verification of two models. European Journal of Soil Science 60:94-109. http://dx.doi.org/10.1111/j.1365-2389.2008.01094.x

Murphy, P. N. C., J. Ogilvie, K. Connor, and P. A. Arp. 2007. Mapping wetlands: a comparison of two different approaches for New Brunswick, Canada. Wetlands 27:846-854. http://dx.doi. org/10.1672/0277-5212(2007)27[846:MWACOT]2.0.CO;2

Natural Resources Canada (NRCAN). 2019. Canadian spatial reference system. Natural Resources Canada, Ottawa, Ontario, Canada. [online] URL: https://www.nrcan.gc.ca/earth-sciences/ geomatics/geodetic-reference-systems/9052
Nogués-Bravo, D., J. I. López-Moreno, and S. M. VicenteSerrano. 2012. Climate change and its impact. Pages 185-200 in I. N. Vogiatzakis, editor. Mediterranean mountain environments. http://dx.doi.org/10.1002/9781119941156.ch9

Parks Canada. 2011. Parks Canada charter. Parks Canada, Ottawa, Ontario, Canada. https://www.pc.gc.ca/en/docs/v-g/ieei/at-ag/agir-action/sec9

Pradervand, J.-N., A. Dubuis, L. Pellissier, A. Guisan, and C. Randin. 2014. Very high resolution environmental predictors in species distribution models: moving beyond topography? Progress in Physical Geography 38:79-96. http://dx.doi. org/10.1177/0309133313512667

Preston, M. I., and A. S. Harestad. 2007. Community and species responses by birds to group retention in a coastal temperate forest on Vancouver Island, British Columbia. Forest Ecology and Management 243:156-167. http://dx.doi.org/10.1016/j.foreco.2007.03.002

R Core Team. 2015. R: a language and environment for statistical computing. R Foundation for Statistical Computing, Vienna, Austria. [online] URL: http://www.r-project.org/

Ralston, J., D. I. King, W. V. DeLuca, G. J. Niemi, M. J. Glennon, J. C. Scarl, and J. D. Lambert. 2015. Analysis of combined data sets yields trend estimates for vulnerable spruce-fir birds in northern United States. Biological Conservation 187:270-278. http://dx.doi.org/10.1016/j.biocon.2015.04.029

Ramsey, P., S. Santilli, R. Obe, M. Cave-Ayland, and B. Park. 2011. Post GIS. Version 2.0. Open Source Geospatial Foundation, Beaverton, Oregon. [online] URL: https://postgis.net/

Reitsma, L. R., M. Goodnow, M. T. Hallworth, and C. J. Conway. 2010. Canada Warbler (Cardellina canadensis). In A. Poole, editor. The birds of North America online. Cornell Lab of Ornithology, Ithaca, New York, USA. [online] URL: https://birdsna.org/ Species-Account/bna/species/canwar/introduction

Reitsma, L. R., J. A. Jukosky, A. J. Kimiatek, M. L. Goodnow, and M. T. Hallworth. 2018. Extra-pair paternity in a long-distance migratory songbird beyond neighbors' borders and across male age classes. Canadian Journal of Zoology 96:49-54. http://dx.doi. org/10.1139/cjz-2016-0277

Robertson, B. A., and R. L. Hutto. 2007. Is selectively harvested forest an ecological trap for Olive-sided Flycatchers? Condor 109:109-121.

Sanderson, E. W., M. Jaiteh, M. A. Levy, K. H. Redford, A. V Wannebo, and G. Woolmer. 2002. The human footprint and the last of the wild. BioScience 52:891-904. http://dx.doi. org/10.1641/0006-3568(2002)052[0891:THFATL]2.0.CO;2

Seely, B. 2011. Final report: Nova Scotia coordinate referencing system (NSCRS): future policy strategy. Service Nova Scotia and Municipal Relations, Geographic Information Services, Halifax, Nova Scotia, Canada. [online] URL: https://geonova.novascotia. ca/file/74/download?token=98qJ_maL

Sirkiä, S., J. Lehtomäki, H. Lindén, E. Tomppo, and A. Moilanen. 2012. Defining spatial priorities for capercaillie Tetrao urogallus lekking landscape conservation in south-central Finland. Wildlife Biology 18:337-353. http://dx.doi.org/10.2981/11-073 
Skagen, S. K., D. A. Granfors, and C. P. Melcher. 2008. On determining the significance of ephemeral continental wetlands to North American migratory shorebirds. Auk 125:20-29. http:// dx.doi.org/10.1525/auk.2008.125.1.20

Sólymos, P., S. M. Matsuoka, E. M. Bayne, S. R. Lele, P. Fontaine, S. G. Cumming, D. Stralberg, F. K. A. Schmiegelow, and S. J. Song. 2013. Calibrating indices of avian density from nonstandardized survey data: making the most of a messy situation. Methods in Ecology and Evolution 4:1047-1058. http://dx.doi. org/10.1111/2041-210X.12106

Sólymos, P., S. M. Matsuoka, S. G. Cumming, D. Stralberg, P. Fontaine, F. K. A. Schmiegelow, S. J. Song, and E. M. Bayne. 2018. Evaluating time-removal models for estimating availability of boreal birds during point-count surveys: sample size requirements and model complexity. Condor 120:765-786. http:// dx.doi.org/10.1650/CONDOR-18-32.1

Spies, T. A., B. C. McComb, R. S. H. Kennedy, M. T. McGrath, K. Olsen, and R. J. Pabst. 2007. Potential effects of forest policies on terrestrial biodiversity in a multi-ownership province. Ecological Applications 17:48-65. http://dx.doi.org/10.1890/1051-0761 (2007)017[0048:PEOFPO]2.0.CO;2

Stralberg, D., E. M. Bayne, S. G. Cumming, P. Sólymos, S. J. Song, and F. K. A. Schmiegelow. 2015b. Conservation of future boreal forest bird communities considering lags in vegetation response to climate change: a modified refugia approach. Diversity and Distributions 21:1112-1128. http://dx.doi.org/10.1890/13-2289.1. sm

Stralberg, D., S. Matsuoka, A. Hamann, E. Bayne, P. Solymos, F. K. A. Schmiegelow, X. Wang, S. Cumming, and S. Song. 2015c. Appendix D. Individual species climate-change projections from projecting boreal bird responses to climate change: the signal exceeds the noise. [online] URL: https://doi.org/10.6084/m9. figshare.3546822.v1

Stralberg, D., S. M. Matsuoka, A. Hamann, E. M. Bayne, P. Solymos, F. K. A. Schmiegelow, X. Wang, S. G. Cumming, and S. J. Song. 2015a. Projecting boreal bird responses to climate change: the signal exceeds the noise. Ecological Applications 25:52-69. http://dx.doi.org/10.1890/13-2289.1

Stralberg, D., S. M. Matsuoka, C. M. Handel, F. K. A. Schmiegelow, A. Hamann, and E. M. Bayne. 2017. Biogeography of boreal passerine range dynamics in western North America: past, present, and future. Ecography 40:1050-1066. https://doi. org/10.1111/ecog.02393

Taper, M. L. 2004. Model identification from many candidates. In M. L. Taper and S. R. Lele, editors. Nature of scientific evidence: statistical, philosophical, and empirical considerations. University of Chicago Press, Chicago, Illinois, USA. http://dx.doi. org/10.7208/chicago/9780226789583.003.0015
United States Geological Survey (USGS) and Environment and Climate Change Canada (ECCC). 2018. North American breeding bird survey. United States Geological Survey, Washington, D.C., USA and Environment and Climate Change Canada, Ottawa, Ontario, Canada. [online] URL: https://www.pwrc.usgs.gov/ BBS/

Vankerham, R. 2015. Conservation areas reporting and tracking system database. Canadian Council on Ecological Areas. [online] URL: http://www.ccea.org/carts/

Veloz, S., L. Salas, B. Altman, J. D. Alexander, D. Jongsomjit, N. Elliott, and G. Ballard. 2015. Improving effectiveness of systematic conservation planning with density data. Conservation Biology 29:1217-1227. http://dx.doi.org/10.1111/cobi.12499

Warner, B. G., and C. Rubec. 1997. The Canadian wetland classification system. Second edition. Wetlands Research Centre, University of Waterloo, Waterloo, Ontario, Canada. [online] URL: http://www.gret-perg.ulaval.ca/fileadmin/fichiers/fichiersGRET/ pdf/Doc_generale/Wetlands.pdf

Westwood, A. R. 2016. Conservation of three forest landbird species at risk: characterizing and modelling habitat at multiple scales to guide management planning. Dissertation. Department of Biology, Dalhousie University, Halifax, Nova Scotia, Canada. [online] URL: https://dalspace.library.dal.ca/handle/10222/71405

Westwood, A. R., C. Harding, L. Reitsma, and D. Lambert. 2017. Guidelines for managing Canada Warbler habitat in the Atlantic northern forest of Canada. High Branch Conservation Services, Hartland, Vermont, USA. [online] URL: http://www.borealbirds. ca/files/Technical_Reports/CAWA_BCR14_HabMgmt_en.pdf

White, B., J. Ogilvie, D. M. H. Campbell, D. Hiltz, B. Gauthier, H. K. Chisholm, H. K. Wen, P. N. C. Murphy, and P. A. Arp. 2012. Using the cartographic depth-to-water index to locate small streams and associated wet areas across landscapes. Canadian Water Resources Journal 37:333-347. http://dx.doi.org/10.4296/ cwrj2011-909

Woolmer, G., S. C. Trombulak, J. C. Ray, P. J. Doran, M. G. Anderson, R. F. Baldwin, A. Morgan, and E. W. Sanderson. 2008. Rescaling the human footprint: a tool for conservation planning at an ecoregional scale. Landscape and Urban Planning 87:42-53. http://dx.doi.org/10.1016/j.landurbplan.2008.04.005
Editor-in-Chief: Keith A.Hobson Subject Editor: Marcel Darveau
Sponsored by the Society of Canadian Ornithologists and Bird Studies Canada Parrainée par la Société des ornithologistes du Canada et Études d'oiseaux Canada

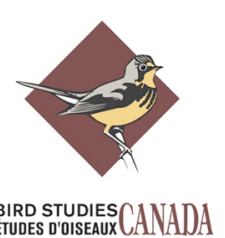


Appendix 1. Point count locations and abundances for Olive-sided Flycatcher and Canada Warbler in New Brunswick and Nova Scotia.

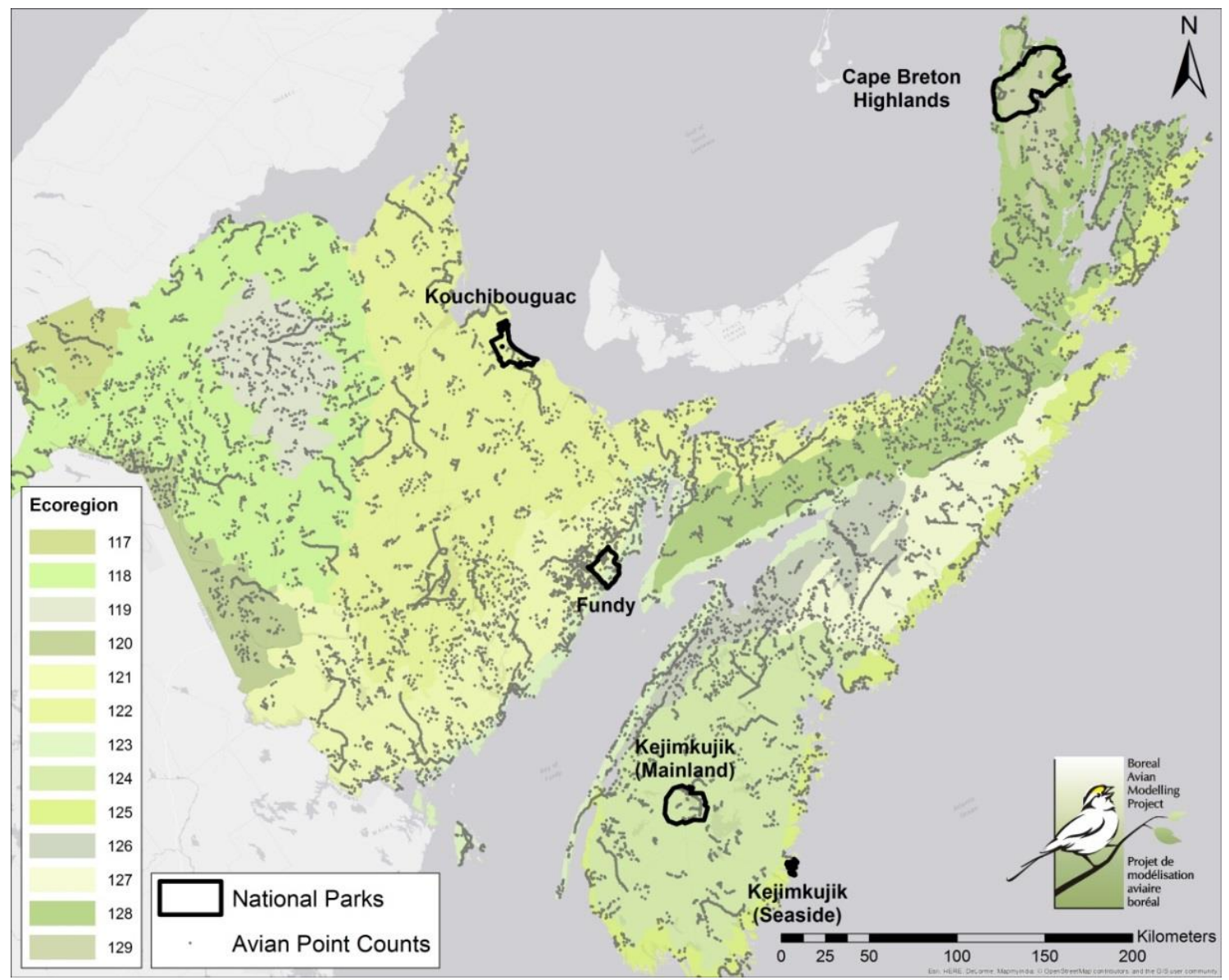

Fig. A.1, Map of the study area in New Brunswick and Nova Scotia, Canada, including the location of all point counts in the Boreal Avian Modelling Project database (Barker et al. 2015), the four studied national parks (excluding the Kejimkujik Seaside adjunct) and 13 ecoregions.

Table A.1, Number of Olive-sided Flycatcher (OSFL) and Canada Warbler (CAWA) observed from 1996-2013 at point counts in Nova Scotia and New Brunswick in the Boreal Avian Modeling project database.

\begin{tabular}{cccccc}
\hline \hline Species & \multicolumn{5}{c}{ Birds at point count locations } \\
& 0 & 1 & 2 & 3 & $\geq 4$ \\
\hline OSFL & 46179 & 776 & 25 & 0 & 0 \\
CAWA & 46322 & 609 & 41 & 7 & 1 \\
\hline
\end{tabular}


Appendix 2. Spatial data layers used for covariate extraction and information for harmonizing wetlands data layers.

Table A2.1, Spatial data layers used for covariate extraction.

\begin{tabular}{|c|c|c|c|c|c|}
\hline Layer & Description & $\begin{array}{l}\text { Data } \\
\text { Year }\end{array}$ & $\begin{array}{c}\text { Resol- } \\
\text { ution } \\
(\mathrm{m})\end{array}$ & Rights & Citations \\
\hline $\begin{array}{l}\text { Avian Point Count } \\
\text { Dataset }\end{array}$ & BAM and BBS project data & 2014 & vector & $\begin{array}{l}\text { Boreal Avian Modelling } \\
\text { Project }\end{array}$ & $\begin{array}{l}\text { Cumming et al. } \\
2010 \text {, Barker et al. } \\
2015\end{array}$ \\
\hline $\begin{array}{l}\text { Common Attribute } \\
\text { Schema for Forest } \\
\text { Resource Inventory } \\
\text { (CASFRI) }\end{array}$ & $\begin{array}{l}\text { National extent of provincial forest } \\
\text { resource inventories, standardized to a } \\
\text { common schema }\end{array}$ & $\begin{array}{l}2008- \\
2014\end{array}$ & vector & & $\begin{array}{l}\text { Cosco 2011, } \\
\text { Cumming et al. } \\
2015\end{array}$ \\
\hline $\begin{array}{l}\text { National } \\
\text { Ecological } \\
\text { Framework for } \\
\text { Canada }\end{array}$ & $\begin{array}{l}\text { Canada's ecological framework, } \\
\text { including ecozones, ecoprovinces, } \\
\text { ecoregions, and ecodistricts. }\end{array}$ & 2013 & vector & $\begin{array}{l}\text { CGDI National Frameworks } \\
\text { Data; Agriculture and Agri- } \\
\text { Food Canada }\end{array}$ & $\begin{array}{l}\text { Marshall et al. } \\
1999\end{array}$ \\
\hline Human Footprint & $\begin{array}{l}\text { Extent and relative intensity of human } \\
\text { influence on terrestrial ecosystems via } \\
\text { human settlement, access, landscape } \\
\text { transformation, and infrastructure }\end{array}$ & $\begin{array}{l}2001- \\
2006\end{array}$ & 90 & $\begin{array}{l}\text { Wildlife Conservation Society } \\
\text { Canada; Conservation } \\
\text { Biology Institute: Data Basin }\end{array}$ & $\begin{array}{l}\text { Sanderson et al. } \\
\text { 2002; Woolmer et } \\
\text { al. } 2008\end{array}$ \\
\hline $\begin{array}{l}\text { Landscape } \\
\text { Complexity }\end{array}$ & $\begin{array}{l}\text { The variety of microclimates on the } \\
\text { landscape as function of topography, } \\
\text { elevation range, and moisture gradients }\end{array}$ & $\begin{array}{l}2001- \\
2006\end{array}$ & 90 & $\begin{array}{l}\text { The Nature Conservancy - } \\
\text { Eastern Conservation Region; } \\
\text { Conservation Biology } \\
\text { Institute: Data Basin }\end{array}$ & $\begin{array}{l}\text { Anderson et al. } \\
\text { 2012; Anderson \& } \\
\text { Clark } 2012\end{array}$ \\
\hline $\begin{array}{l}\text { Local } \\
\text { Connectedness }\end{array}$ & $\begin{array}{l}\text { Strength of structural connections } \\
\text { between natural ecosystems on a local } \\
\text { landscape, measured as outward } \\
\text { permeability of ecological flows from } \\
\text { one cell to its neighbours }\end{array}$ & 2005 & 90 & $\begin{array}{l}\text { The Nature Conservancy - } \\
\text { Eastern Conservation Region; } \\
\text { Conservation Biology } \\
\text { Institute: Data Basin }\end{array}$ & $\begin{array}{l}\text { Anderson et al. } \\
\text { 2012; Anderson \& } \\
\text { Clark } 2012\end{array}$ \\
\hline National Parks & Boundaries of National Parks & 2012 & vector & \multicolumn{2}{|c|}{ Geomatics Canada; Natural Resources Canada } \\
\hline
\end{tabular}




\begin{tabular}{|c|c|c|c|c|c|}
\hline Layer & Description & $\begin{array}{l}\text { Data } \\
\text { Year }\end{array}$ & $\begin{array}{l}\text { Resol- } \\
\text { ution } \\
\text { (m) }\end{array}$ & Rights & Citations \\
\hline $\begin{array}{l}\text { Protected Areas - } \\
\text { NB }\end{array}$ & $\begin{array}{l}\text { Boundaries of Protected Natural Areas } \\
\text { and Provincial Parks In New Brunswick. }\end{array}$ & $\begin{array}{l}2011- \\
2014\end{array}$ & vector & $\begin{array}{l}\text { Department of Natural } \\
\text { Resources/GeoNB }\end{array}$ & \\
\hline $\begin{array}{l}\text { Protected Areas - } \\
\text { NS }\end{array}$ & $\begin{array}{l}\text { Boundaries for National Parks, } \\
\text { Provincial Parks, Provincial Wildlife } \\
\text { Areas, and other protected areas in NS }\end{array}$ & 2013 & vector & $\begin{array}{l}\text { Nova Scotia Parks and } \\
\text { Protected Areas New } \\
\text { Brunswick }\end{array}$ & \\
\hline Roads & Normalized Canadian road network & 2014 & & $\begin{array}{l}\text { Government of Canada; } \\
\text { Natural Resources Canada; } \\
\text { Earth Sciences Sector; Canada } \\
\text { Centre for Mapping and Earth } \\
\text { Observation }\end{array}$ & \\
\hline $\begin{array}{l}\text { Streams and } \\
\text { Waterways - NB }\end{array}$ & $\begin{array}{l}\text { New Brunswick Hydrographic Network, } \\
\text { delineating surface drainage features for } \\
\text { New Brunswick }\end{array}$ & $\begin{array}{l}2012- \\
2014\end{array}$ & vector & $\begin{array}{l}\text { New Brunswick Department } \\
\text { of Natural Resources/GeoNB }\end{array}$ & \\
\hline $\begin{array}{l}\text { Streams and } \\
\text { Waterways - NS }\end{array}$ & $\begin{array}{l}\text { Provincial hydrographic features at } 1: 10 \\
000 \text { scale }\end{array}$ & unk & vector & $\begin{array}{l}\text { Nova Scotia Department of } \\
\text { Natural Resources }\end{array}$ & \\
\hline $\begin{array}{l}\text { Wet Areas } \\
\text { Mapping - NB }\end{array}$ & $\begin{array}{l}\text { Map of depth to water table derived } \\
\text { from digital elevation models, indicating } \\
\text { likelihood of water saturation }\end{array}$ & $\begin{array}{l}2004- \\
2005\end{array}$ & $10 \mathrm{~m}$ & $\begin{array}{l}\text { Forest Watershed Research } \\
\text { Center, University of New } \\
\text { Brunswick }\end{array}$ & $\begin{array}{l}\text { Murphy et al. } \\
2009\end{array}$ \\
\hline $\begin{array}{l}\text { Wet Areas } \\
\text { Mapping - NS }\end{array}$ & $\begin{array}{l}\text { Map of depth to water table derived } \\
\text { from digital elevation models, indicating } \\
\text { likelihood of water saturation }\end{array}$ & unk & $10 \mathrm{~m}$ & $\begin{array}{l}\text { Nova Scotia Department of } \\
\text { Natural Resources }\end{array}$ & $\begin{array}{l}\text { Murphy et al. } \\
2009\end{array}$ \\
\hline Wetlands - NB & $\begin{array}{l}\text { Wetlands identified from 1:10 } 000 \text { aerial } \\
\text { photography, including wetland type, } \\
\text { vegetation, and photograph year }\end{array}$ & $\begin{array}{l}2003- \\
2012\end{array}$ & vector & $\begin{array}{l}\text { NB Department of } \\
\text { Environment and Local } \\
\text { Government }\end{array}$ & $\begin{array}{l}\text { Department of } \\
\text { Natural Resources } \\
\text { Fish and Wildlife } \\
\text { Branch } 2006\end{array}$ \\
\hline Wetlands - NS & $\begin{array}{l}\text { Wetlands identified from 1:10 } 000 \text { aerial } \\
\text { photography, including wetland type, } \\
\text { vegetation, and photograph year, adapted } \\
\text { to the Canadian Wetland Classification } \\
\text { system }\end{array}$ & $\begin{array}{l}2000- \\
2002\end{array}$ & $\begin{array}{l}30 \mathrm{~m} \\
\text { (sharp- } \\
\text { ened } \\
15 \mathrm{~m})\end{array}$ & $\begin{array}{l}\text { Nova Scotia Department of } \\
\text { Natural Resources }\end{array}$ & \\
\hline
\end{tabular}


Table A2.2, Wetland vegetation type equivalencies for New Brunswick and Nova Scotia using the Canadian Wetlands Classification Guide (National Wetlands Working Group 1997).

\begin{tabular}{lll}
\hline \multicolumn{1}{c}{ NB Veg Type } & NS Veg Type Equivalent & Reclassification \\
\hline Forested Hardwood Vegetation & Treed & Treed \\
Forested Softwood Vegetation & Treed & Treed \\
Alders & Low shrub/tall shrub & Shrub \\
Shrub Vegetation, except alders & Low shrub/tall shrub & Shrub \\
Emergent Vegetation & Graminoid & Graminoid \\
Open Water & Aquatic Vegetation & Aquatic \\
Open Water Un-vegetated & Water & Water/Exposed \\
Coastal/Shoreline Feature Vegetated & Salt Marsh & (excluded) \\
Coastal/Shoreline Feature & none & (excluded) \\
None & Exposed & Water/Exposed \\
\hline
\end{tabular}


Appendix 3. Selection frequencies of covariates across three model subsets for estimating population density of the Olive-sided Flycatcher and Canada Warbler. Covariate full names and descriptions are available in Tables 1 and 2.

Table A3.1, Selection frequencies of covariates at each model stage across three subsets of 240 bootstrapped log-linear Poisson model runs for Olive-sided Flycatcher. Covariates are labelled by buffer size, local (L) and territory (T).

\begin{tabular}{|c|c|c|c|c|}
\hline Stage & Subset & Covariate & $\mathrm{F}$ & $\%$ \\
\hline \multirow{4}{*}{ 1-2. Wetness \& Forest Cover } & WETxFOR & CASFRIxWET_PROP & 218 & 90.8 \\
\hline & WETLANDS & WET_LENGTH (T), CASFRI (T) & 16 & 6.7 \\
\hline & WETNESS & WET_LENGTH (T), CASFRI (T) & 4 & 1.7 \\
\hline & WETNESS & DTW_STD (T), CASFRI (T) & 2 & 0.8 \\
\hline \multirow{11}{*}{ 3. Forest Structure } & WETxFOR & HT_STD (T) & 116 & 48.3 \\
\hline & WETxFOR & CANCL_AV (L) & 56 & 23.3 \\
\hline & WETxFOR & CANCL_STD (L) & 39 & 16.2 \\
\hline & WETLANDS & CANCL_AV (L) & 11 & 4.6 \\
\hline & WETxFOR & HT_AV local & 7 & 2.9 \\
\hline & WETNESS & CANCL_AV (L) & 4 & 1.7 \\
\hline & WETLANDS & HT_STD (T) & 2 & 0.8 \\
\hline & WETLANDS & CANCL_STD (L) & 2 & 0.8 \\
\hline & WETNESS & HT_STD (T) & 1 & 0.4 \\
\hline & WETNESS & CANCL_AV (T) & 1 & 0.4 \\
\hline & WETLANDS & HT_AV local & 1 & 0.4 \\
\hline \multirow{6}{*}{ 4. Landscape Complexity } & WETxFOR & COMPLEXITY (T) & 171 & 71.2 \\
\hline & WETxFOR & Null & 47 & 19.6 \\
\hline & WETLANDS & COMPLEXITY (T) & 12 & 5.0 \\
\hline & WETNESS & COMPLEXITY (T) & 4 & 1.7 \\
\hline & WETLANDS & Null & 4 & 1.7 \\
\hline & WETNESS & Null & 2 & 0.8 \\
\hline \multirow{3}{*}{ 5. Disturbance } & WETxFOR & FOOTPRINT (T) & 218 & 90.8 \\
\hline & WETLANDS & FOOTPRINT (T) & 16 & 6.7 \\
\hline & WETNESS & FOOTPRINT (T) & 6 & 2.5 \\
\hline \multirow{6}{*}{ 6. Road Distance } & WETxFOR & Null & 211 & 87.9 \\
\hline & WETLANDS & Null & 11 & 4.6 \\
\hline & WETxFOR & ROAD (L) & 7 & 2.9 \\
\hline & WETNESS & Null & 5 & 2.1 \\
\hline & WETLANDS & ROAD (L) & 5 & 2.1 \\
\hline & WETNESS & ROAD (L) & 1 & 0.4 \\
\hline \multirow{5}{*}{ 7. Landscape Connectivity } & WETxFOR & CONNECT $(\mathrm{T})$ & 119 & 49.6 \\
\hline & WETxFOR & NULL & 99 & 41.2 \\
\hline & WETLANDS & CONNECT $(\mathrm{T})$ & 14 & 5.8 \\
\hline & WETNESS & CONNECT $(\mathrm{T})$ & 6 & 2.5 \\
\hline & WETLANDS & Null & 2 & 0.8 \\
\hline
\end{tabular}




\begin{tabular}{ccccc}
\hline \hline Stage & Subset & Covariate & F & $\%$ \\
\hline \multirow{3}{*}{ 8. Protection Status } & WETxFOR & Null & 149 & 62.1 \\
& WETxFOR & PROTECT (L) & 69 & 28.8 \\
& WETLANDS & Null & 9 & 3.8 \\
& WETNESS & Null & 8 & 3.3 \\
& WETLANDS & PROTECT (L) & 7 & 2.9 \\
& WETNESS & PROTECT (L) & 3 & 1.2 \\
& WETNESS & Null & 3 & 1.2 \\
\hline
\end{tabular}


Table A3.2, Selection frequencies of covariates at each model stage across three subsets of 240 bootstrapped log-linear Poisson model runs for Canada Warbler. Covariates are labelled by buffer size, local (L) and territory (T). Column title abbreviations: $\mathrm{F}=$ Frequency, $\%=$ Percent selected.

\begin{tabular}{|c|c|c|c|c|}
\hline Stage & Subset & Covariate & $\mathrm{F}$ & $\%$ \\
\hline \multirow{4}{*}{ 1-2. Wetness \& Forest Cover } & WETNESS & DTW_STD (T), CASFRI (T) & 185 & 77.1 \\
\hline & WETNESS & DTW_STD (T), CASFRI (L) & 52 & 21.7 \\
\hline & WETxFOR & CASFRIxDTW_PROP $(\mathrm{T})$ & 2 & 0.8 \\
\hline & WETNESS & DTW_STD (T), Null & 1 & 0.4 \\
\hline \multirow[t]{6}{*}{ 3. Forest Structure } & WETNESS & CANCL_STD (L) & 144 & 60 \\
\hline & WETNESS & HT_STD $(\mathrm{T})$ & 68 & 28.3 \\
\hline & WETNESS & CANCL_AV $(\mathrm{T})$ & 12 & 5 \\
\hline & WETNESS & CANCL_AV (L) & 8 & 3.3 \\
\hline & WETNESS & $\mathrm{HT} \_\mathrm{AV}(\mathrm{L})$ & 6 & 2.5 \\
\hline & WETxFOR & CANCL_STD (L) & 2 & 0.8 \\
\hline \multirow[t]{4}{*}{ 4. Landscape Complexity } & WETNESS & COMPLEXITY (T) & 230 & 95.8 \\
\hline & WETNESS & Null & 8 & 3.3 \\
\hline & WETxFOR & Null & 1 & 0.4 \\
\hline & WETxFOR & COMPLEXITY (T) & 1 & 0.4 \\
\hline \multirow[t]{3}{*}{ 5. Disturbance } & WETNESS & FOOTPRINT (T) & 226 & 94.2 \\
\hline & WETNESS & CASFRI_DIST (T) & 12 & 5 \\
\hline & WETxFOR & FOOTPRINT (T) & 2 & 0.8 \\
\hline \multirow[t]{3}{*}{ 6. Road Distance } & WETNESS & Null & 203 & 84.6 \\
\hline & WETNESS & ROAD (L) & 35 & 14.6 \\
\hline & WETxFOR & Null & 2 & 0.8 \\
\hline \multirow[t]{2}{*}{ 7. Landscape Connectivity } & WETNESS & CONNECT (T) & 238 & 99.2 \\
\hline & WETxFOR & CONNECT $(\mathrm{T})$ & 2 & 0.8 \\
\hline \multirow[t]{4}{*}{ 8. Protection Status } & WETNESS & Null & 128 & 53.3 \\
\hline & WETNESS & PROTECT (L) & 110 & 45.8 \\
\hline & WETxFOR & Null & 1 & 0.4 \\
\hline & WETxFOR & PROTECT (L) & 1 & 0.4 \\
\hline
\end{tabular}


Table A3.3, Top ranked covariates explaining variation in density estimates for the Olive-sided Flycatcher and Canada Warbler for each model subset. Models represent the most-selected variable from each stage of the model-building process. Scale of variable is indicated as local (L) or territory $(\mathrm{T})$.

\begin{tabular}{ccc}
\hline \hline Species & Subset & Top ranked model \\
OSFL & WETLAND & Count $\sim$ WET_LENGTH $(\mathrm{T})+$ CASFRI $(\mathrm{T})+$ HT_STD $(\mathrm{T})+$ COMPLEX $(\mathrm{T})+$ \\
& S & FOOTPRINT $(\mathrm{T})+$ CONNECT $(\mathrm{T})$ \\
& WETNESS & Count $\sim$ DTW_STD $(\mathrm{T})+$ CASFRI $(\mathrm{T})+$ HT_STD $(\mathrm{T})+$ COMPLEX $(\mathrm{T})+$ \\
& FOOTPRINT $(\mathrm{T})+$ CONNECT $(\mathrm{T})$
\end{tabular}



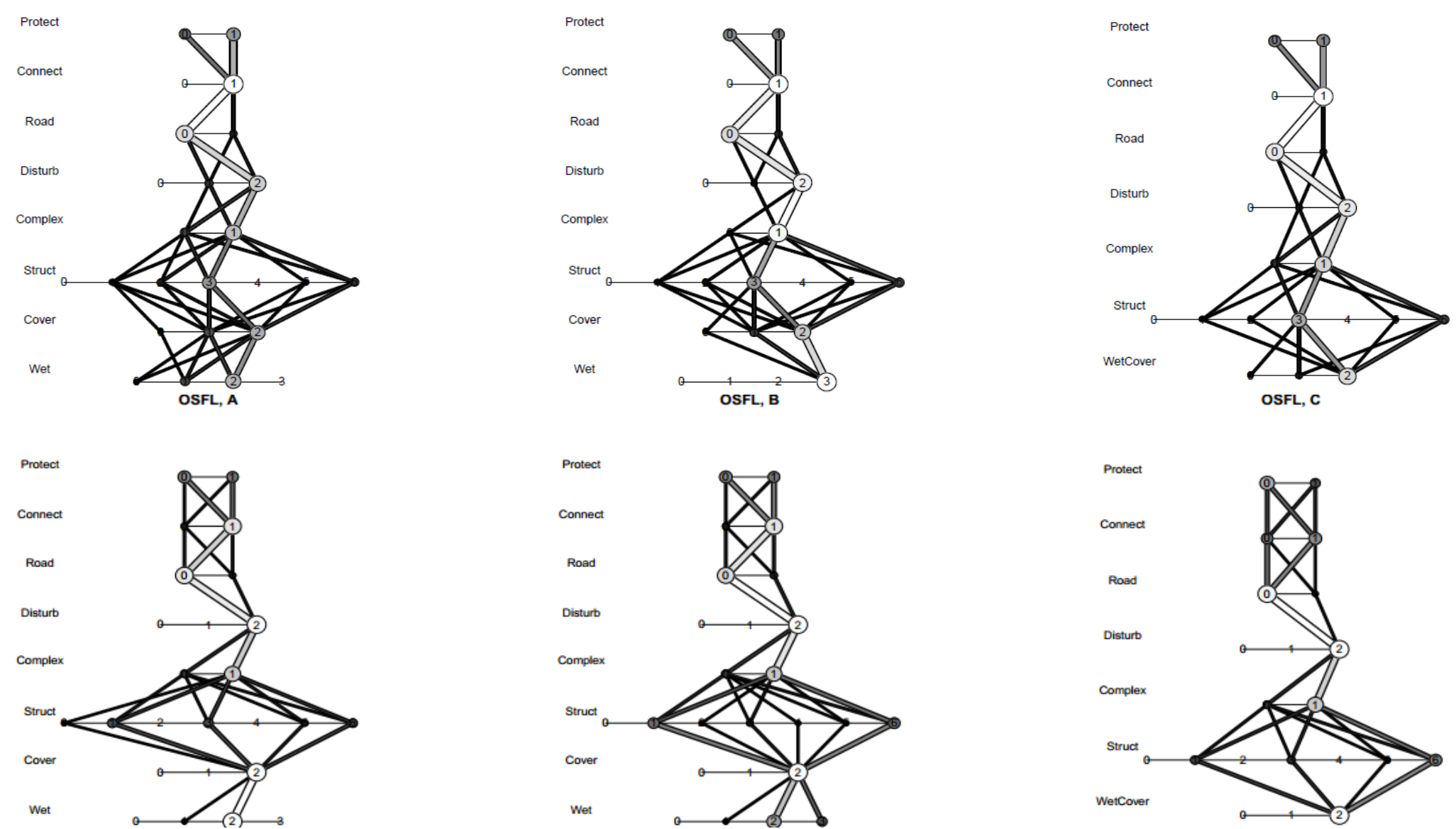

Fig A3.1, Selection paths of variables best explaining variation in density estimation of Olive-sided Flycatcher and Canada Warbler in New Brunswick and Nova Scotia based on the branching hierarchy model building process. Results for three model subsets (A - WETLANDS, B - WETNESS, C - WETxFOR) represent selection frequencies from 240 bootstrap iterations. Horizontal lines show each model stage, and numbers indicate individual covariates. Shade and thickness of line are proportional to selection frequency, with thicker lines of lighter shades indicating higher selection frequencies. 
Appendix 4. Results for effects of individual covariates on density estimates for the Olive-sided Flycatcher and Canada Warbler in New Brunswick and Nova Scotia.
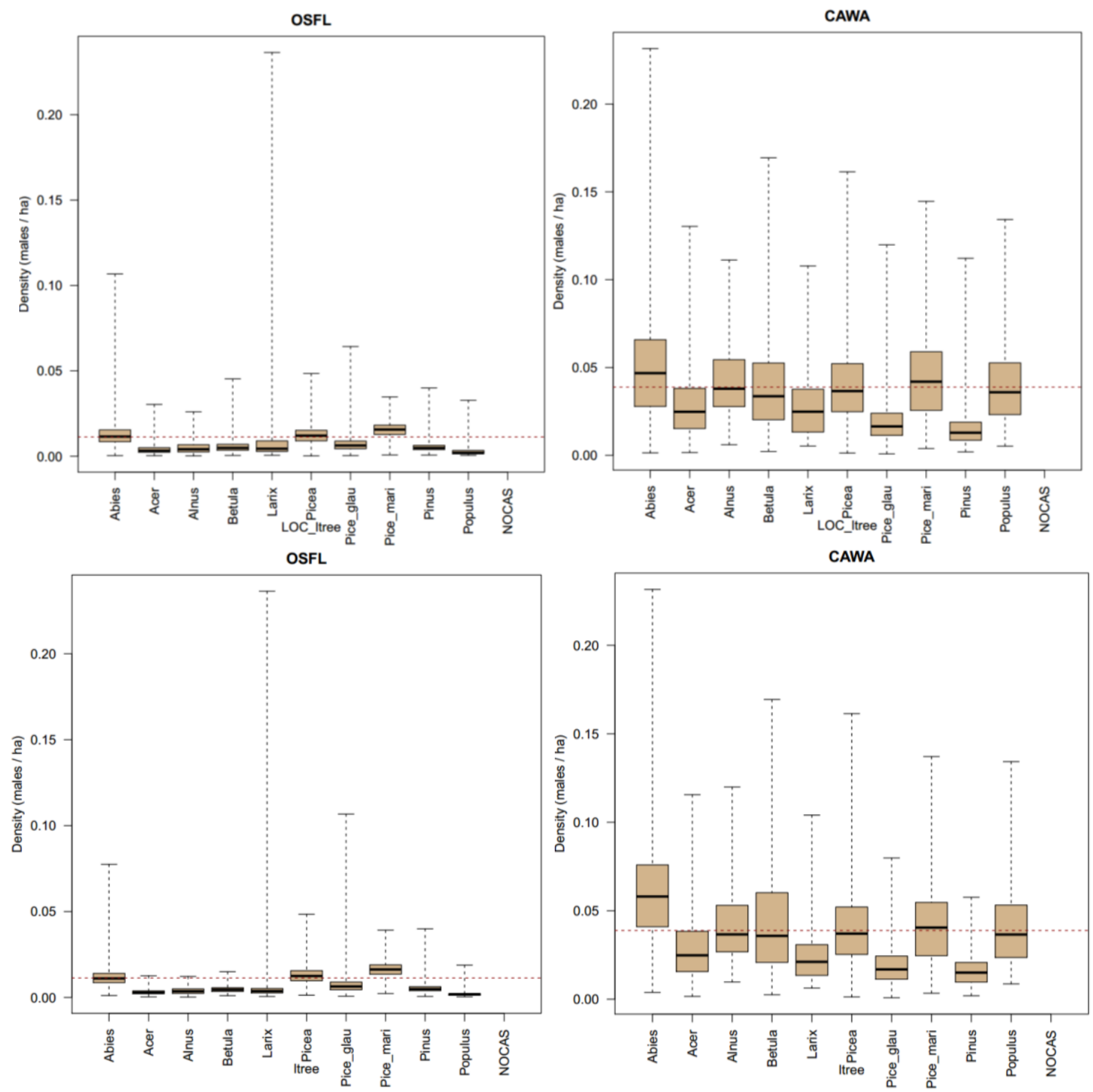

Fig. A4.1, Relationship of predicted density to forest cover at two scales for Olive-sided Flycatcher (OSFL; WETxFOR model subset), and Canada Warbler (CAWA; WETNESS model subset). Upper panels show the local scale (50m buffer for CAWA, 100m for OSFL) and lower panels show territory scale ( $250 \mathrm{~m}$ buffer). 

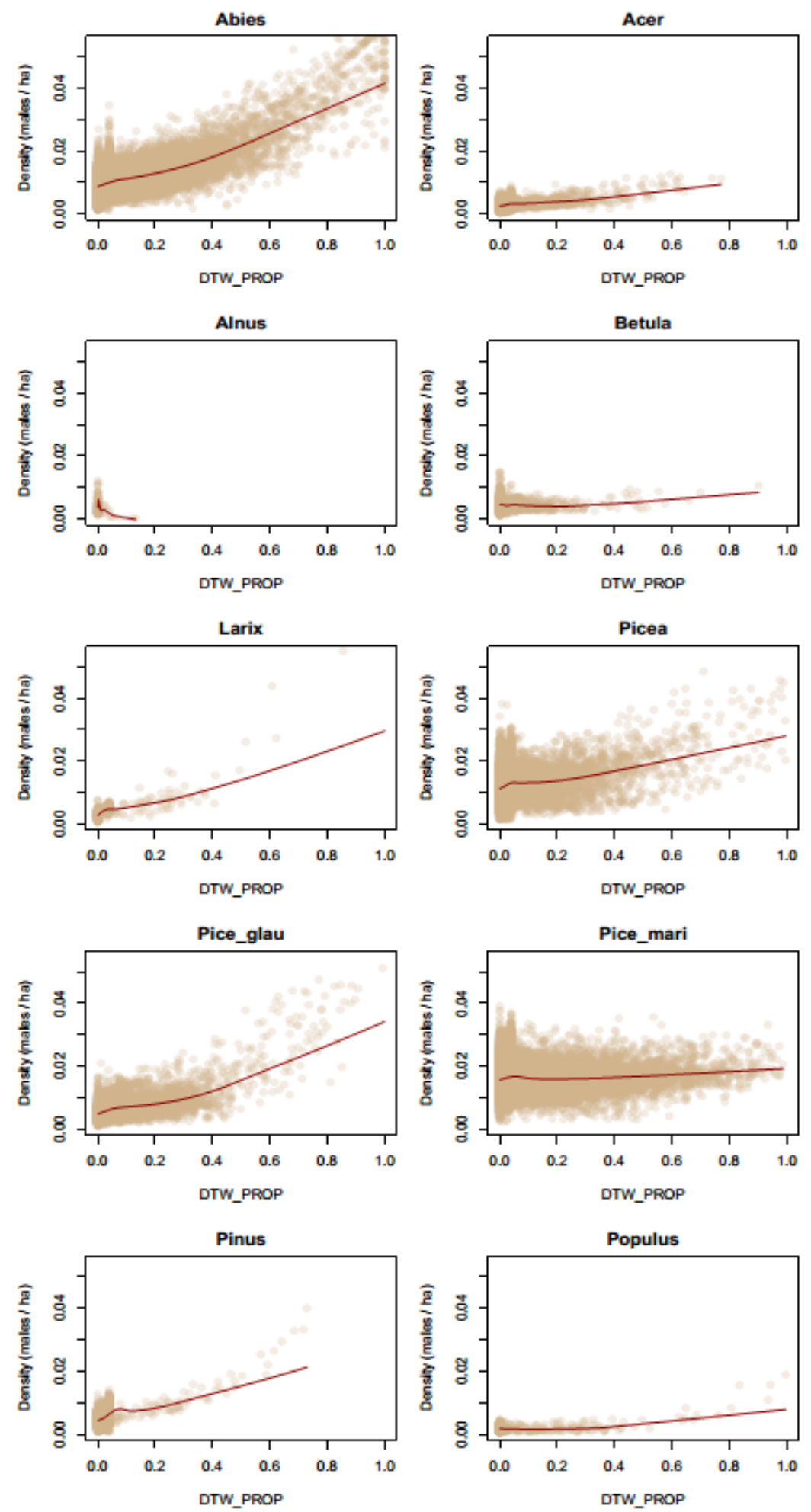

Fig. A4.2, Relationship of predicted density to forest cover and proportion of buffer classified as wet (depth to water table $\leq 1 \mathrm{~m}$ ) at the territory scale $(250 \mathrm{~m}$ ) for the Olive-sided Flycatcher. Values on the $\mathrm{X}$ axis are standardized. 

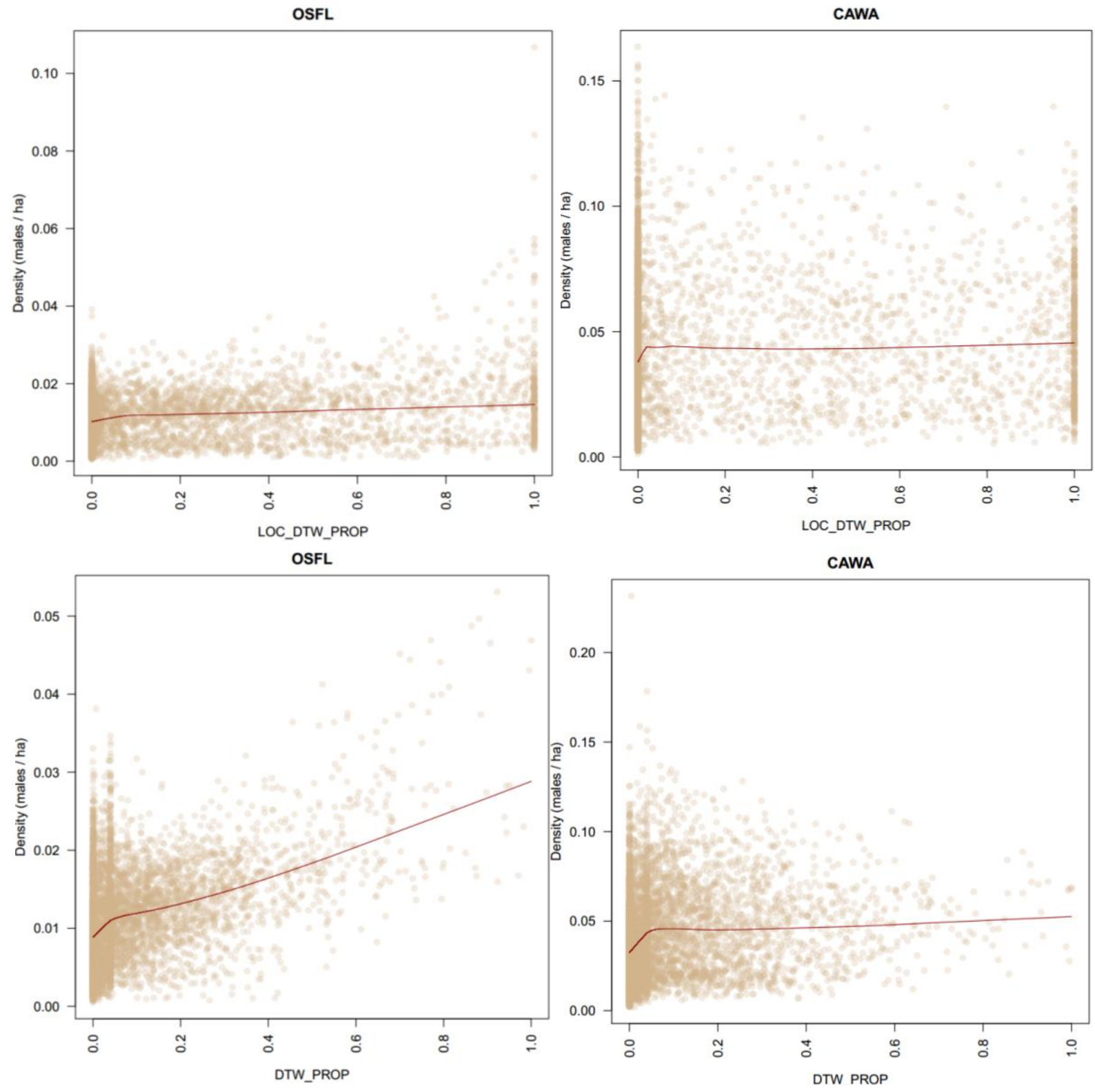

Fig. A4.3, Relationship of density of males per hectare to proportion of depth to water table classified as $<=1$ in buffers for for the Olive-sided Flycatcher (OSFL; WETxFOR model subset) and CAWA (CAWA; WETNESS model subset). Upper panels show the local scale (50m buffer for CAWA, 100m for OSFL) and lower panels show territory scale (250 $\mathrm{m}$ buffer). Values on the $\mathrm{X}$ axis are standardized. 


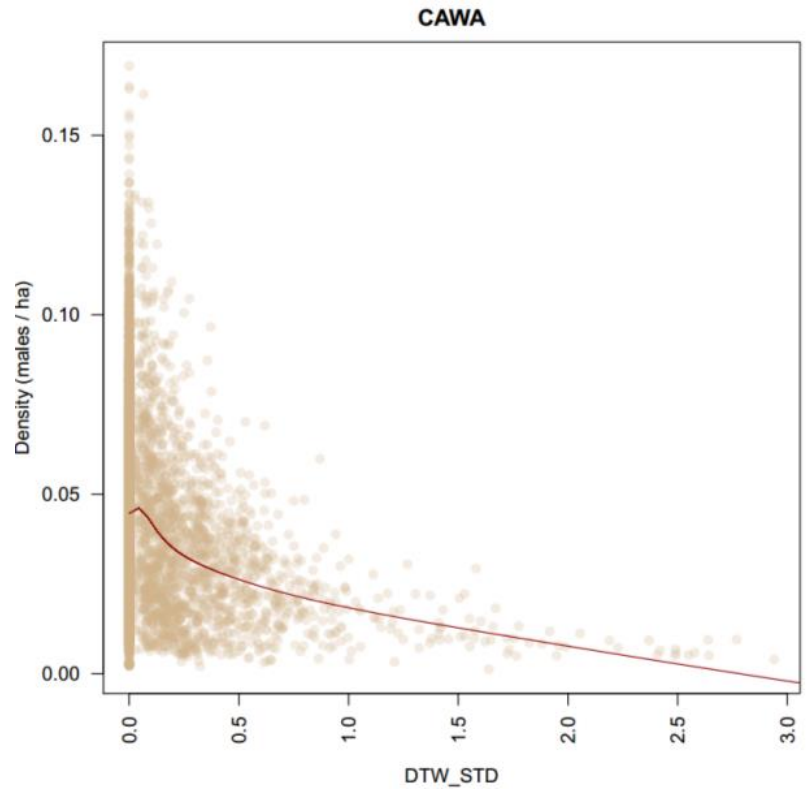

Fig. A4.5, Relationship of predicted density of males per hectare to standard deviation of depth to water table at the territory scale $(250 \mathrm{~m}$ ) for Canada Warbler (WETNESS model subset). Values on the X axis are standardized. 

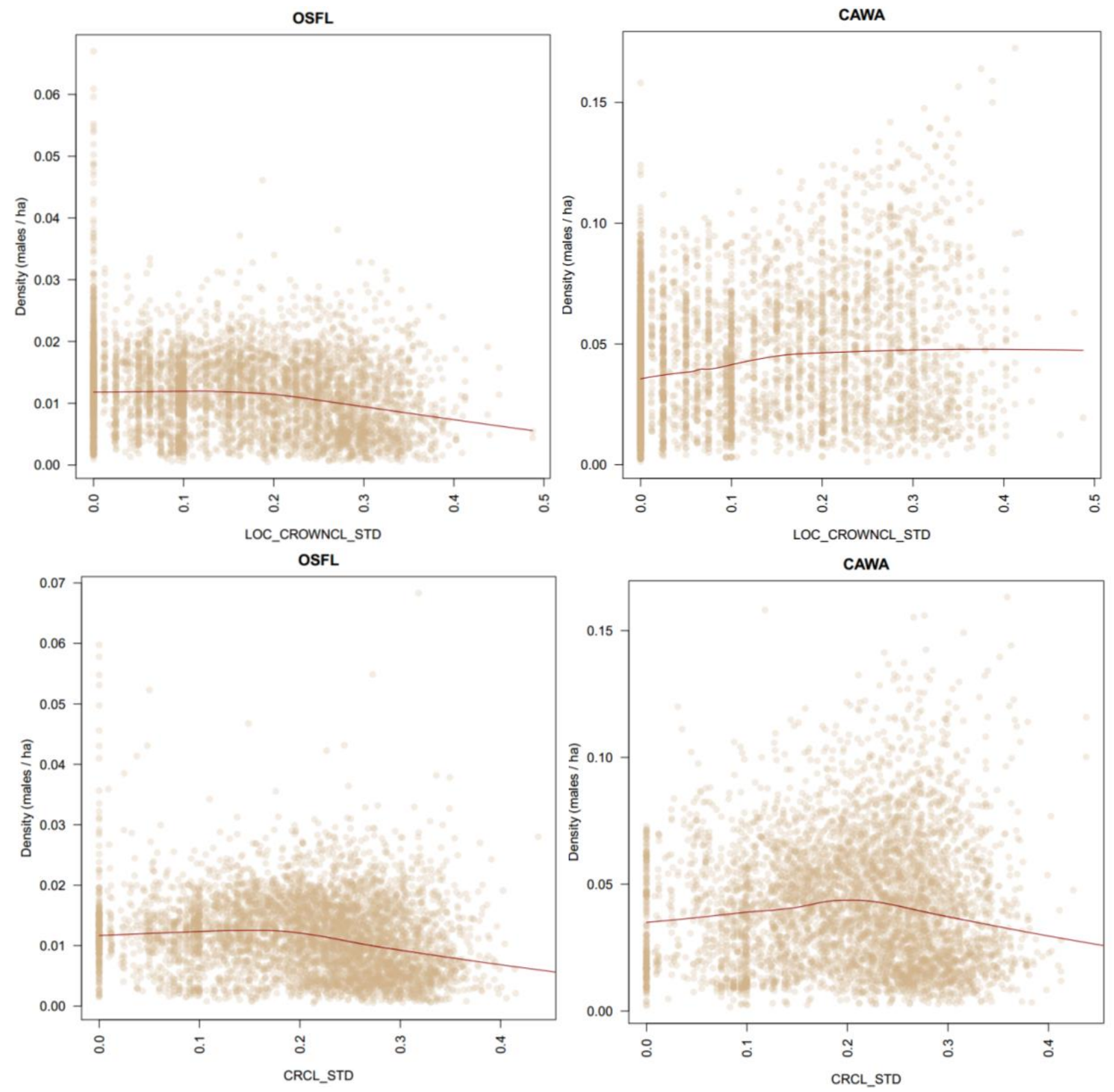

Fig. A4.6, Relationship of predicted density of males per hectare to mean and standard deviation of canopy closure at two scales for the Olive-sided Flycatcher (OSFL; WETxFOR model subset) and Canada Warbler (CAWA; WETNESS model subset). Upper panels show mean canopy height at the local scale (50m buffer for CAWA, 100m for OSFL) and lower panels show standard deviation of canopy height at the territory scale $(250 \mathrm{~m}$ buffer). Values on the $\mathrm{X}$ axis are standardized. 

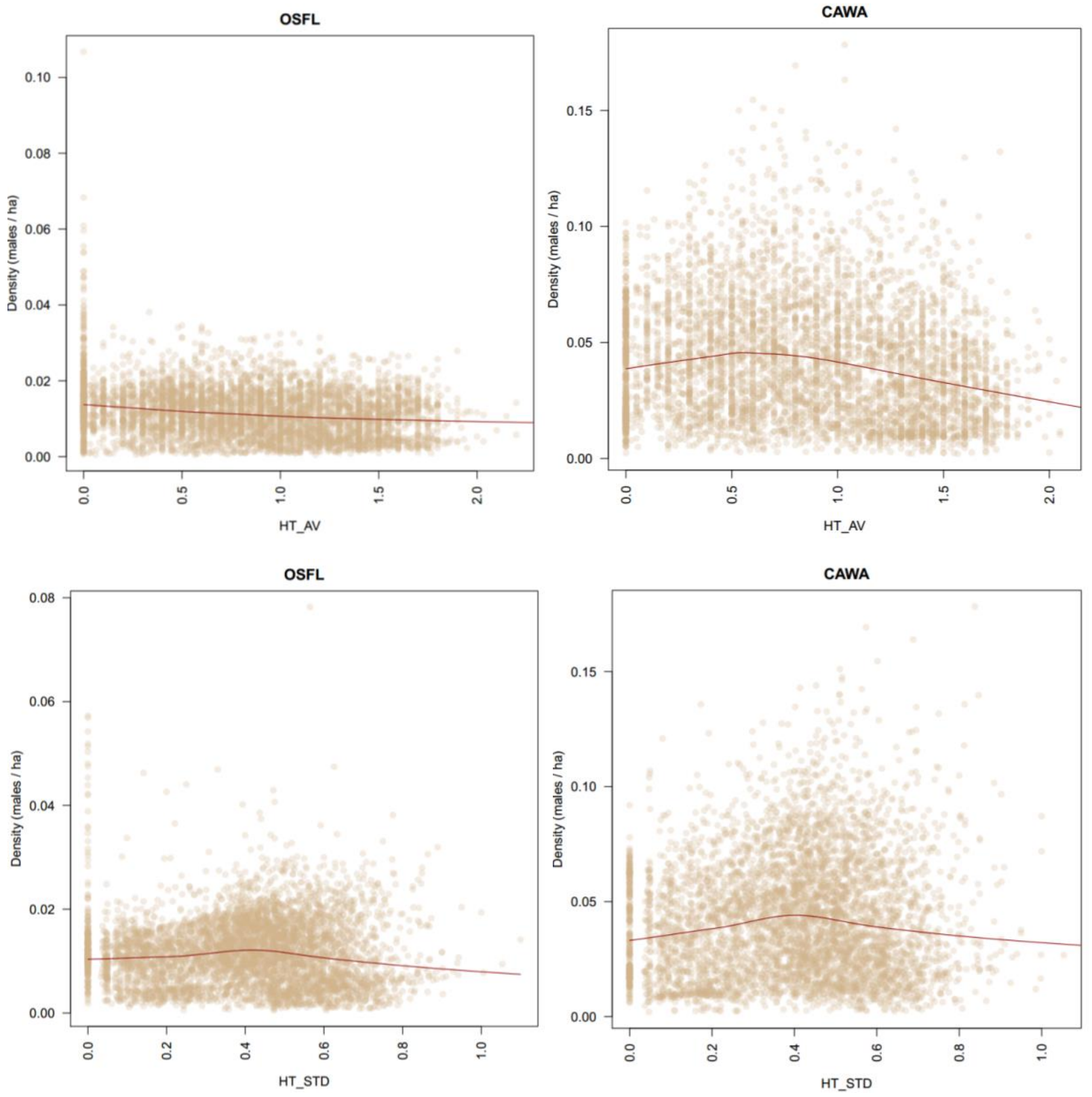

Fig. A4.7, Relationship of predicted density of males per hectare to mean and standard deviation of canopy height at two scales for Olive-sided Flycatcher (OSFL; WETxFOR model subset) and Canada Warbler (CAWA; WETNESS model subset). Upper panels show mean canopy height at the local scale (50m buffer for CAWA, 100m for OSFL) and lower panels show standard deviation of canopy height at the territory scale (250m buffer). Values on the $\mathrm{X}$ axis are standardized. 

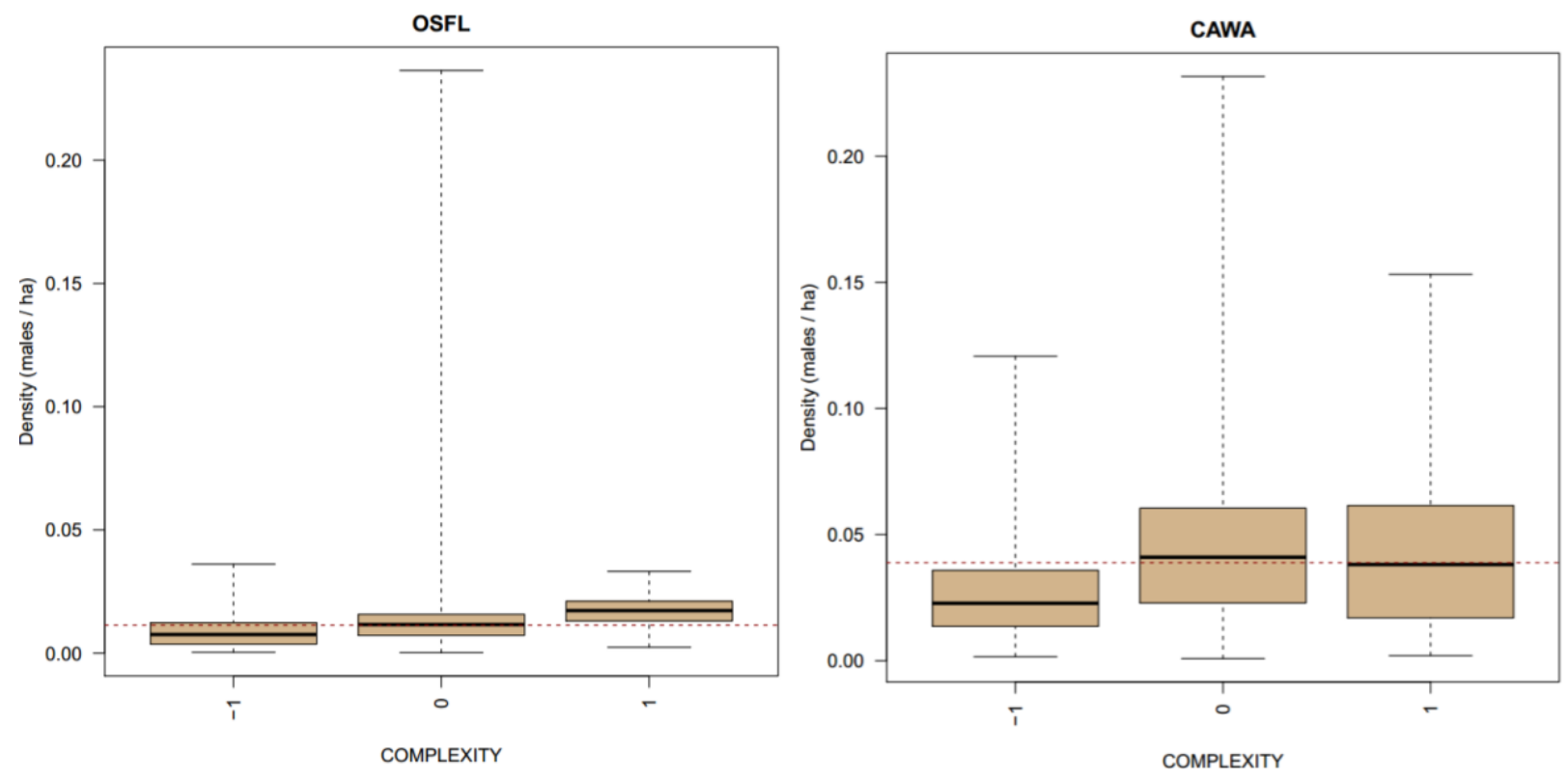

Fig. A4.8, Relationship of density of males per hectare to landscape complexity $(-1=$ below mean, $0=$ mean, $1=$ above mean $)$ at the territory scale (250 $\mathrm{m}$ buffer) for the Olive-sided Flycatcher (OSFL; WETxFOR model subset) and CAWA (CAWA; WETNESS model subset).
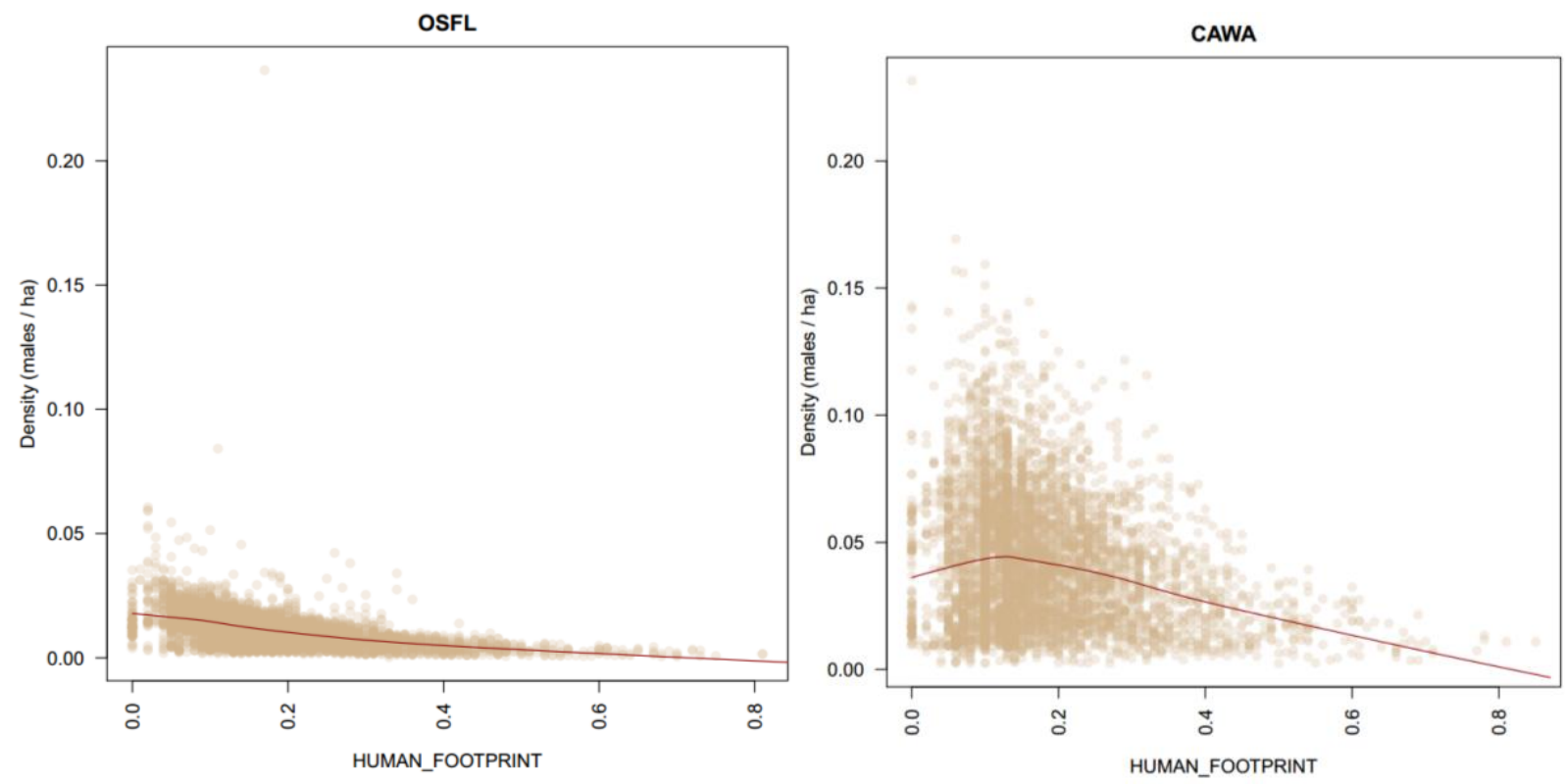

Fig. A4.9, Relationship of density of males per hectare to human footprint index at the territory scale $(250 \mathrm{~m})$ for the Olive-sided Flycatcher (OSFL; WETxFOR model subset) and CAWA (CAWA; WETNESS model subset). Values on the $\mathrm{X}$ axis are standardized. 

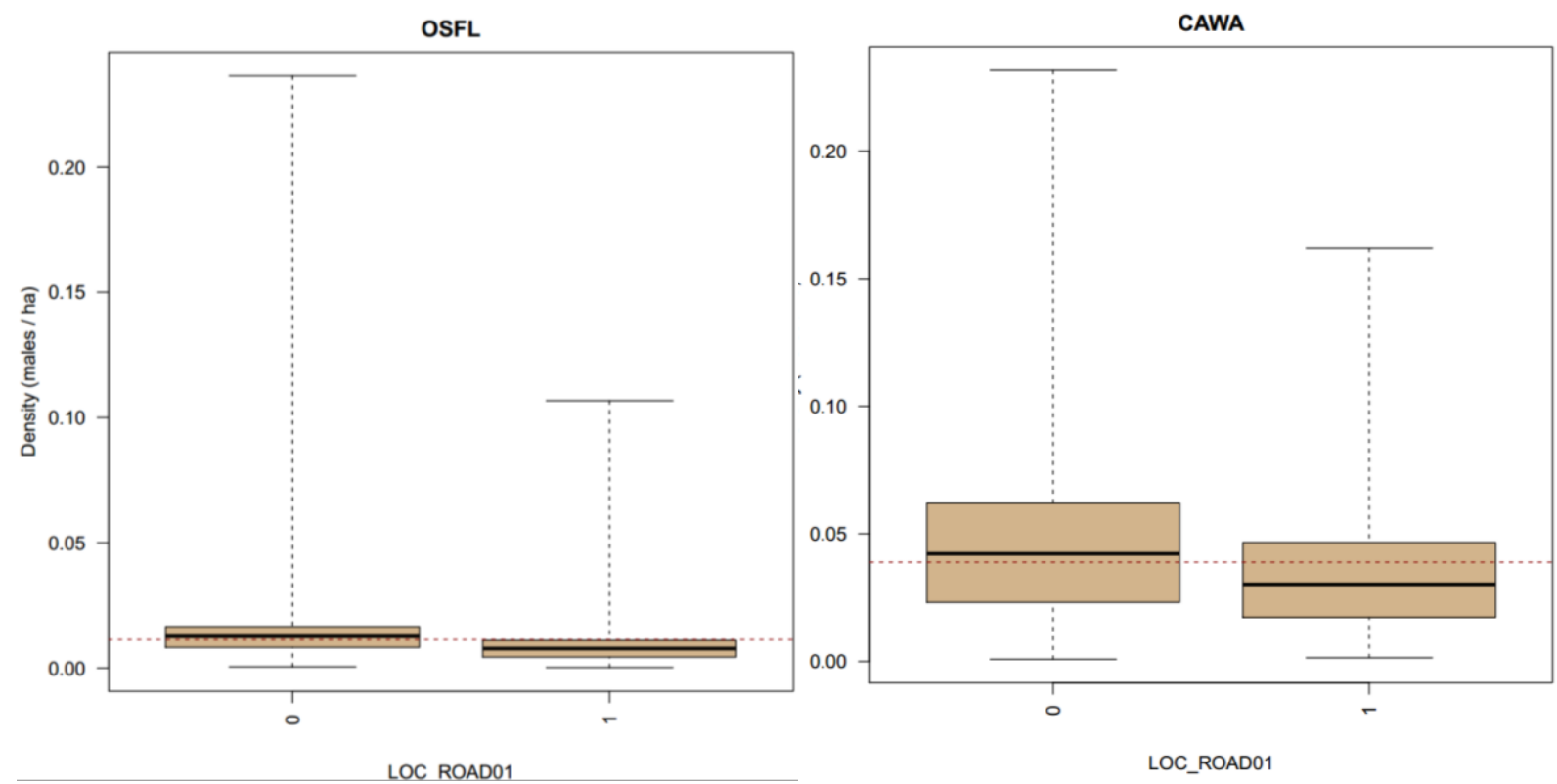

Fig. A4.10, Relationship of density of males per hectare to road condition $(0=$ point count off road, 1 = point count adjacent to road) for the Olive-sided Flycatcher (OSFL; WETxFOR model subset) and CAWA (CAWA; WETNESS model subset).
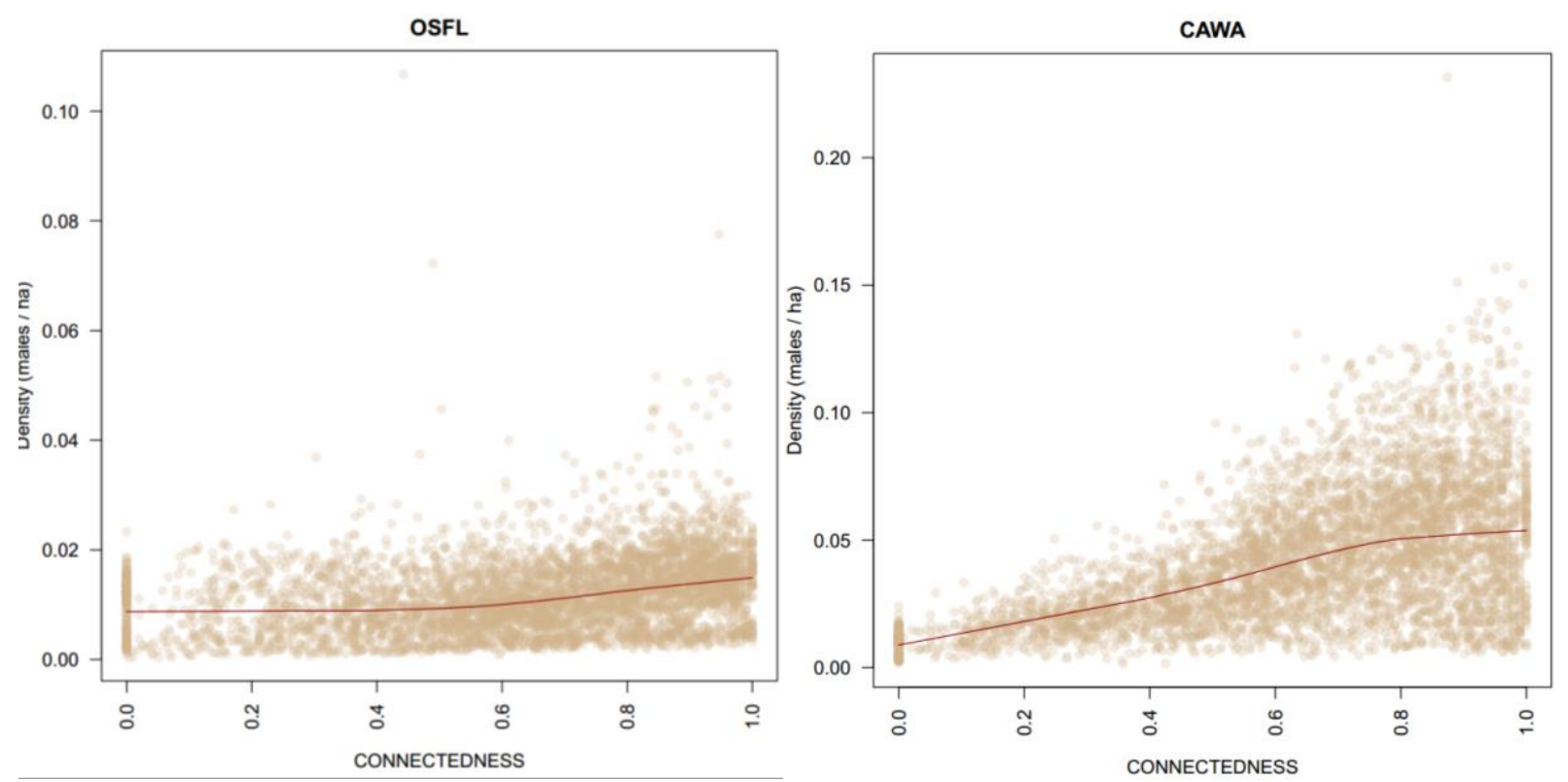

Fig. A4.11, Relationship of density of males per hectare to local connectedness index at the territory scale $(250 \mathrm{~m}$ ) for the Olive-sided Flycatcher (OSFL; WETxFOR model subset) and CAWA (CAWA; WETNESS model subset). Values on the $\mathrm{X}$ axis are standardized. 

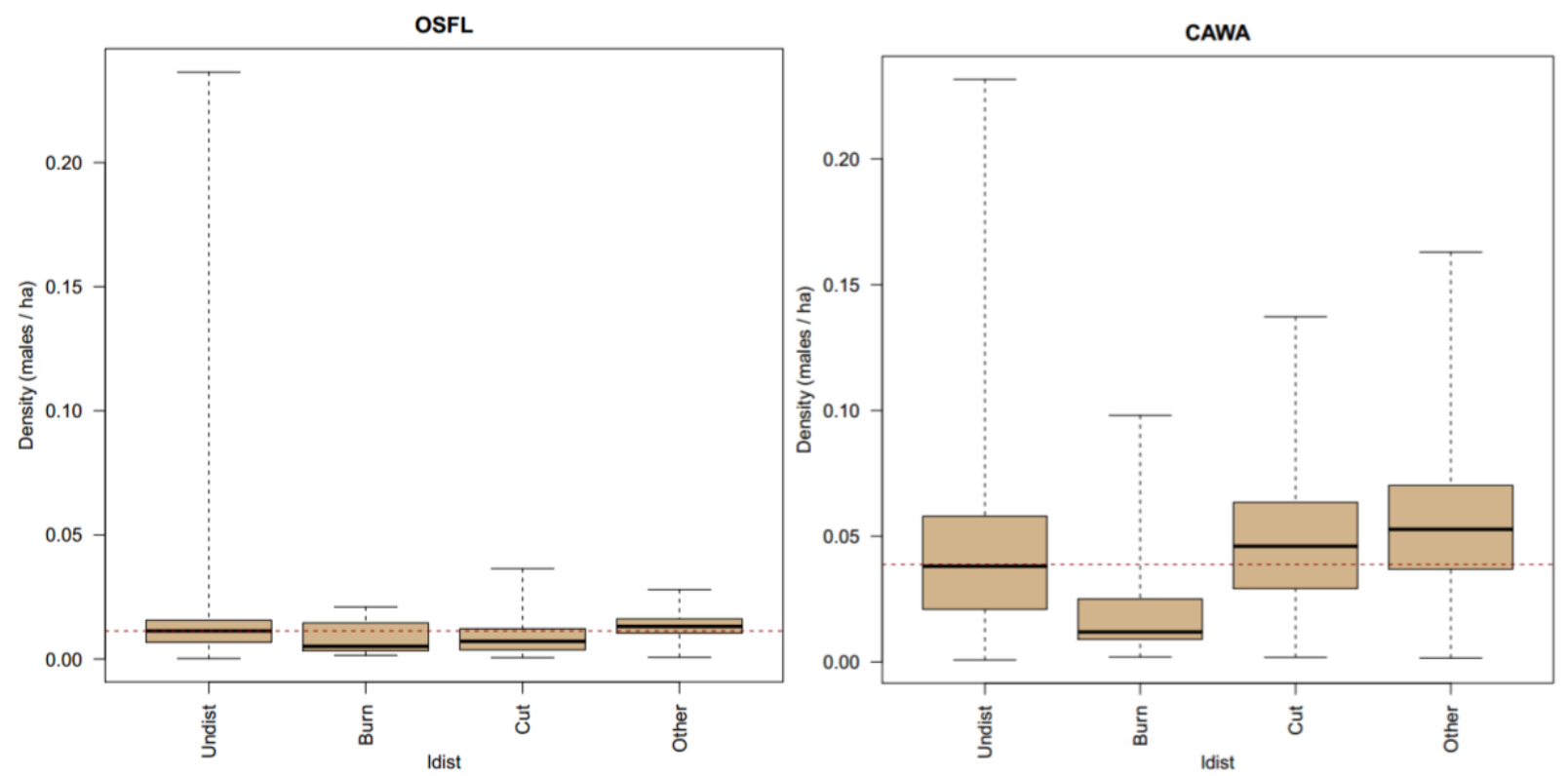

Fig. A4.12, Relationship of density of males per hectare to disturbed area within the territory buffer $(250 \mathrm{~m})$ for the Olive-sided Flycatcher (OSFL; WETxFOR model subset) and CAWA (CAWA; WETNESS model subset).
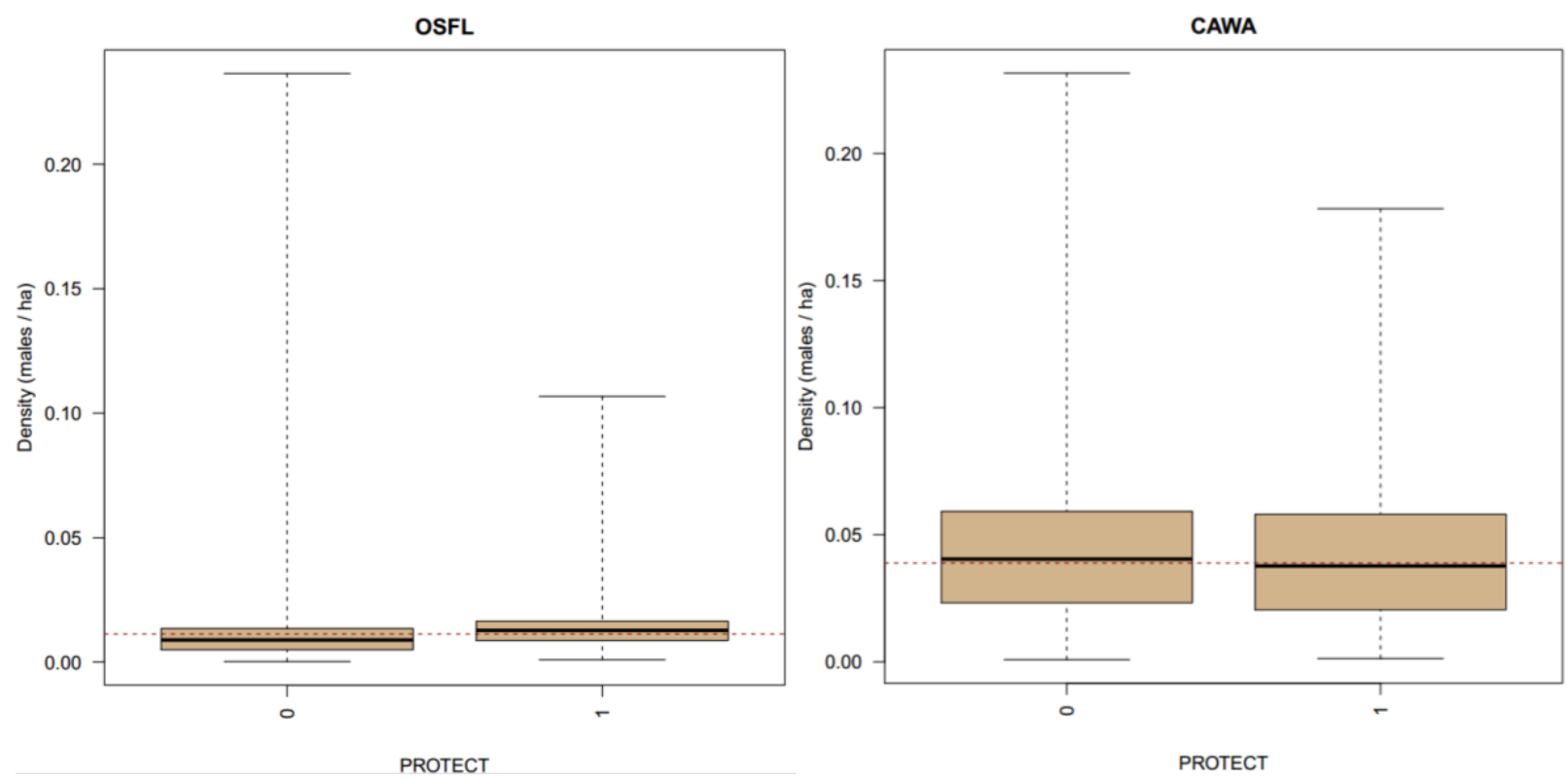

Fig. A4.13, Relationship of density of males per hectare to site protection status at the point count location $(0=$ unprotected, $1=$ protected $)$ for the Olive-sided Flycatcher (OSFL; WETxFOR model subset) and CAWA (CAWA; WETNESS model subset). 
Appendix 5. Maps of density estimates for Olive-sided Flycatcher and Canada Warbler in four national parks in New Brunswick and Nova Scotia.

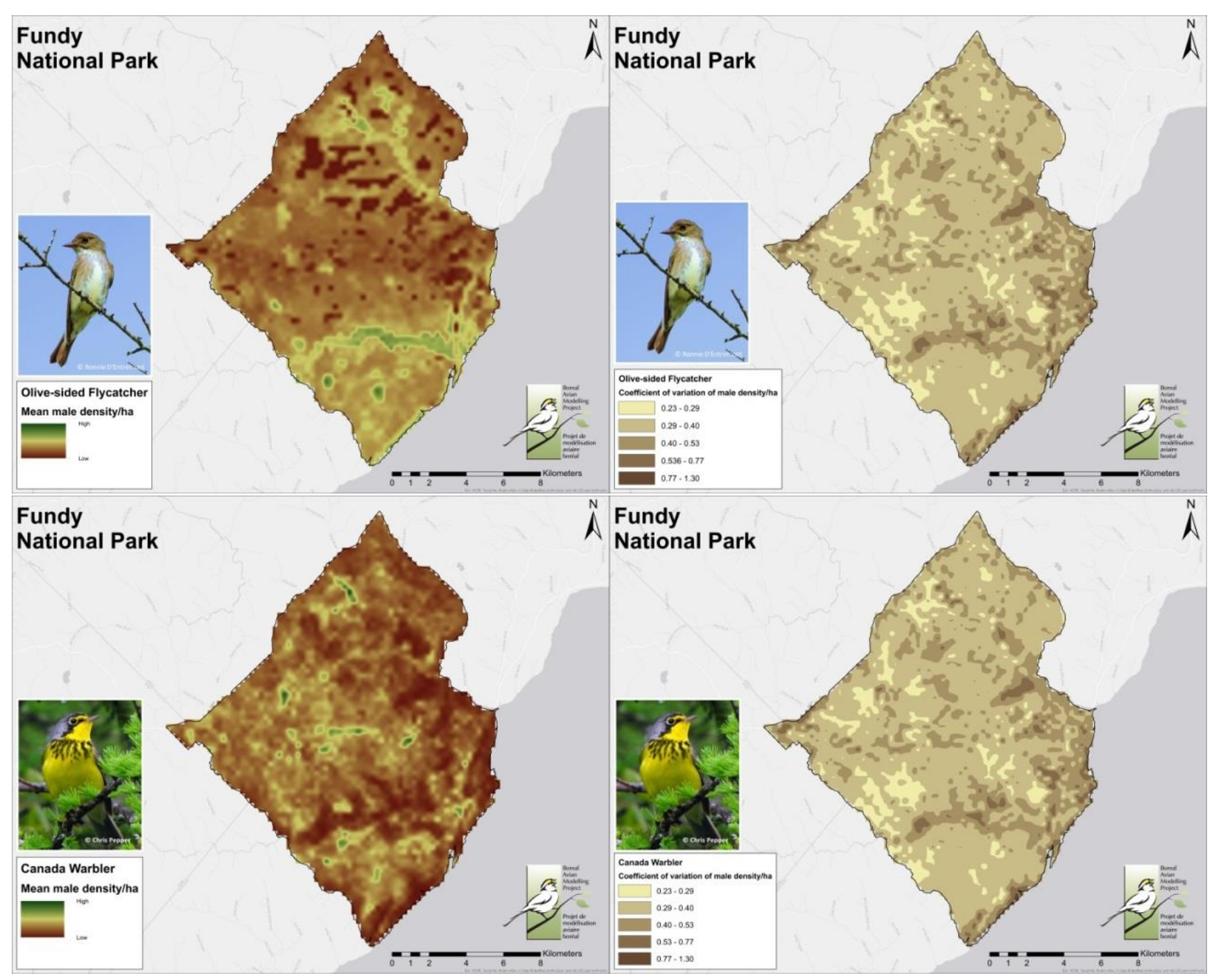

Fig. A5.1, Predicted mean density of territorial males/ha (left panels) and coefficient of variation (right panels) for Olive-sided Flycatcher and Canada Warbler in Fundy National Park, New Brunswick, Canada. 


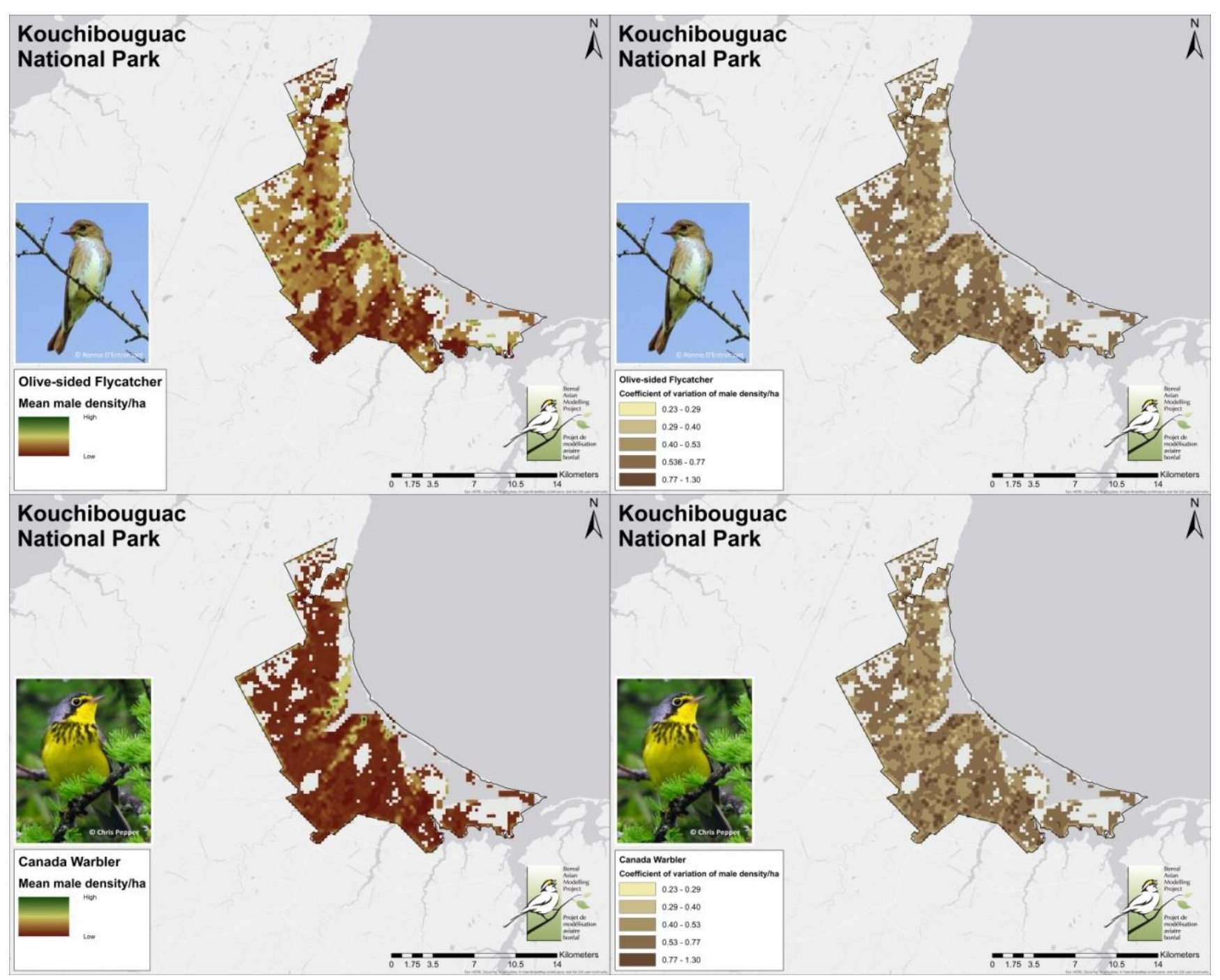

Fig. A5.2, Predicted mean density (left panels) and coefficient of variation (right panels) for Olive-sided Flycatcher and Canada Warbler in Kouchibouguac National Park. 


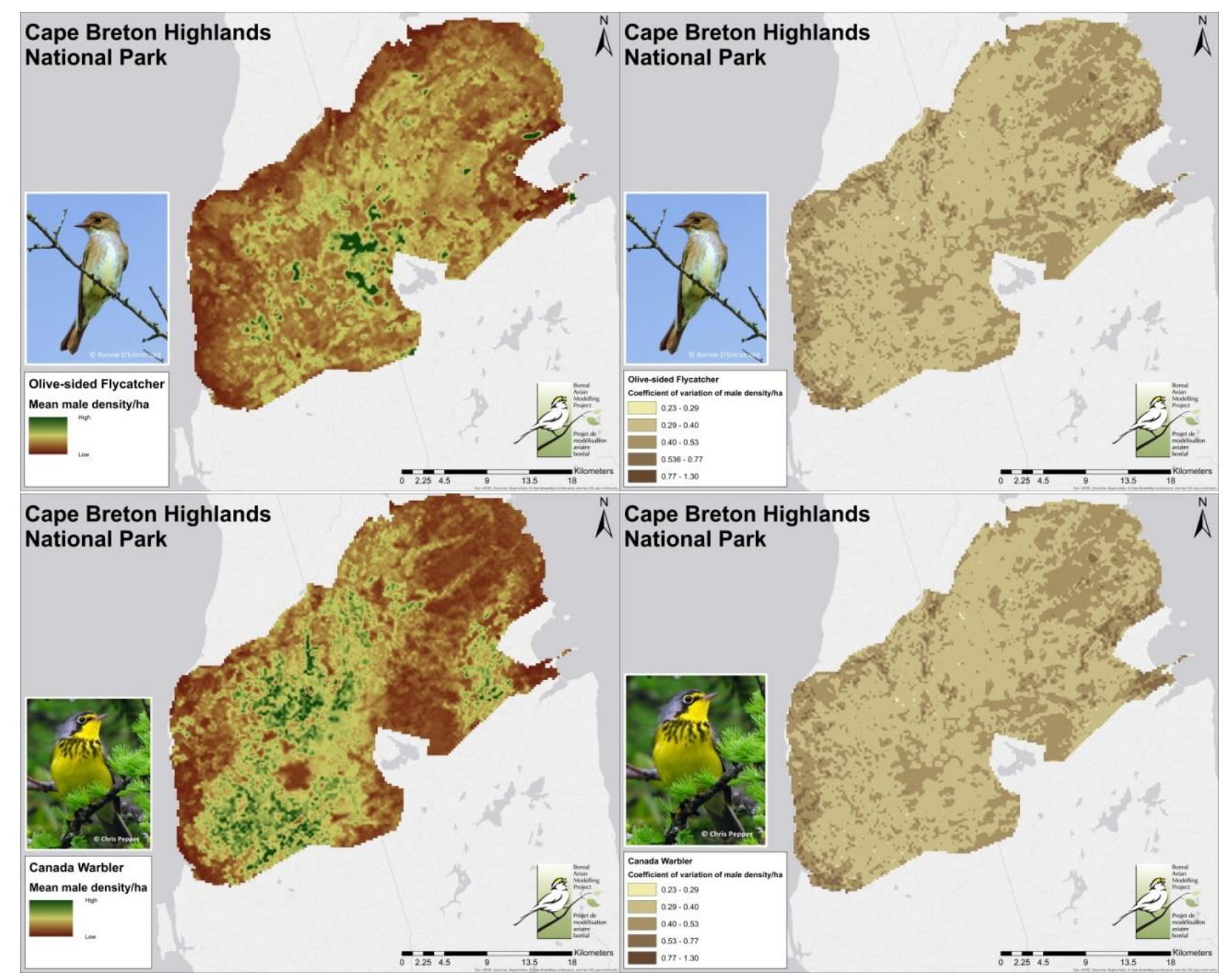

Fig. A5.3, Predicted mean density (left panels) and coefficient of variation (right panels) for Olive-sided Flycatcher and Canada Warbler in Cape Breton Highlands National Park. 


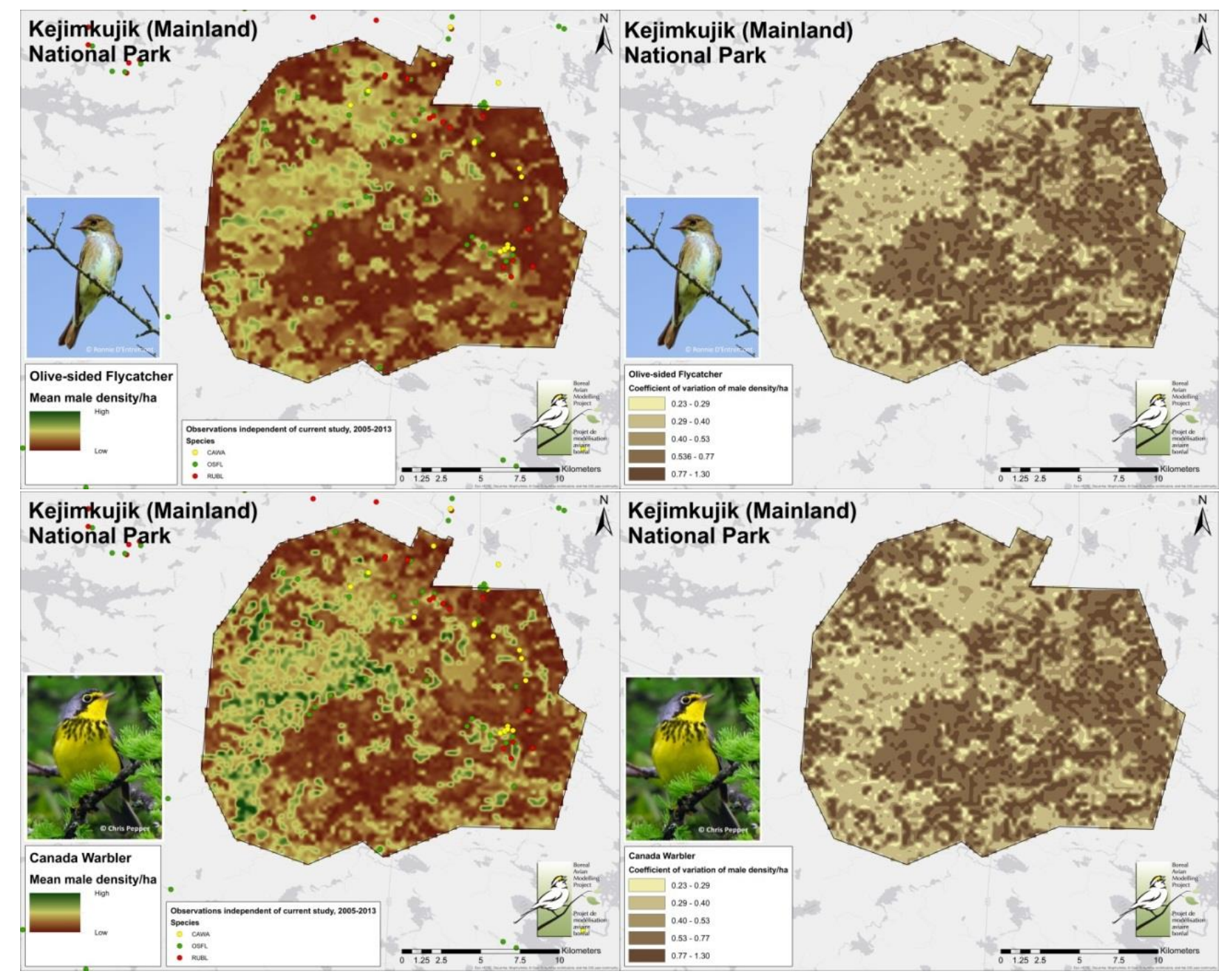

Fig. A5.4, Predicted mean density (left panels) and coefficient of variation (right panels) for Olive-sided Flycatcher and Canada Warbler in Kejimkujik Mainland National Park. Left panels show recent known locations of the study species as well as the Rusty Blackbird, another species at risk using wet forest landscapes, for comparison (authors' dataset). 